Mitteilungen der Österreichischen Geographischen Gesellschaft,

151. Jg. (Jahresband), Wien 2009, S. 53-87

\title{
How to Lure the New Argonauts to Austria? Brain Competition Policy in a Small Open European Economy
}

\author{
Christian REINER, Salzburg*
}

with 6 Fig. and 1 Table in the text and 2 Appendices

\section{Contents}

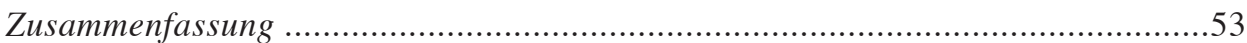

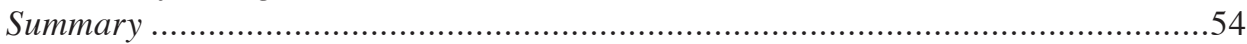

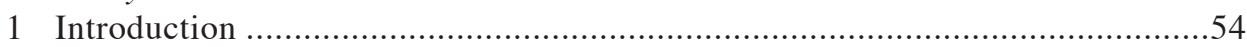

2 Country size matters! The case of small open economies …............................58

3 The Austrian paradox and the business sector........................................67

4 Austria's "European Paradox" and the university sector ................................72

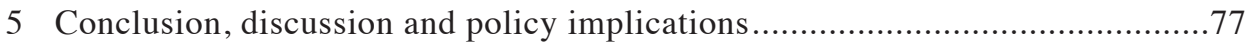

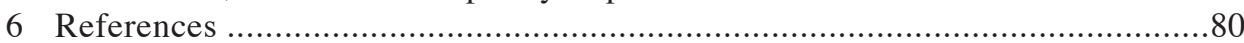

\section{Zusammenfassung}

Wie lockt man die „,neuen Argonauten“ nach Österreich? Brain Competition Policy in kleinen offenen Volkswirtschaften

Humankapital ist ein zentraler Inputfaktor für die Wettbewerbsfähigkeit reicher Staaten und Regionen. Eine Nachfrageexpansion nach hochqualifizierten Arbeitskräften sowie ein Standortwettbewerb um diese sind die Folge. Wirtschafts- und Regionalpolitiker versuchen durch eine Reihe von Maßnahmen, hier zusammengefasst unter dem Begriff "Brain Competition Policy" (BCP), Standorte für in- und ausländische hochqualifizierte Arbeitskräfte zu attraktivieren. Der erste Teil des Aufsatzes belegt anhand von vier "Stylised Facts" die hohe Bedeutung von BCP und ausländischen hochqualifizierten Arbeitskräften für kleine offene Volkswirtschaften. Danach wird die Situation Österreichs im Wettbewerb um Hochqualifizierte anhand der industriellen Spezialisierung und universitären Performance, unter Berücksichtigung pfadabhängiger Prozesse und des sektoralen Wandels erörtert. Es zeigt sich, dass die schlechte Wettbewerbsposition Österreichs (,,brain drain anstatt brain gain“) nicht zuletzt durch den Mangel an high-tech-Industrien sowie mit einem nur mittelmäßigen Universitätssystem erklärt werden kann.

* Mag. Christian ReIner, Assistant for Economic Geography, University of Salzburg, Hellbrunnerstraße 34, A-5020 Salzburg; e-mail: christian.reiner@sbg.ac.at, http://www.uni-salzburg.at/geographie 


\section{Summary}

Human capital is one of the key input factors for the competitiveness of developed countries and regions. As a result, demand and locational competition for highlyskilled individuals has sharply increased. Policy agents react by taking several policy measures, denoted here as "brain competition policy" $(B C P)$. The first part of the paper analyses the relevance of attracting and retaining talent for small open economies and proves the high importance of BCP and foreign talent for these countries to manage their internationalisation of innovation, production and trade by means of four stylised facts. The second part describes the case of Austria along the lines of industrial specialisation and university performance taking into account patterns of path-dependency and structural change. It emerges, that the rather weak competitiveness of Austria in the competition for talent, i.e. "brain drain instead of brain gain", can be - inter alia - explained by an unfavourabely large share of non-high-tech industries and a mediocre university performance.

\section{Introduction $^{1)}$}

The "New Argonauts" are - according to SAXENIAN (2006) - US-educated immigrant engineers of mainly Indian and Chinese origin, acting as cross-regional entrepreneurs by circulating between Silicon Valley and their start-ups in their home regions, thereby functioning as "knowledge spillover agents" (BERGMAn \& SCHUBERT 2005), questioning the simple dichotomy of brain drain and brain gain and transforming former non-high tech and poor regions into newly emerging high-tech clusters. Thinking of the New Argonauts as highly-skilled individuals in general or the "creative class" as FloridA (2007) puts it, it is no wonder that policy agents at different spatial scales are eager to lure New Argonauts to reap the gains associated with the spillover of new knowledge to the regional economy (ILO 2006; OECD 2009). "Battle for brains" or "war for talent" are just two buzzwords to denote new forms of competition between jurisdictions.

Indeed, economic growth and competitiveness of developed nations and regions are increasingly based on the ability of firms to innovate and upgrade products, processes and organisations (MAskell \& Malmberg 1999; Audretsch 2001). The recent shortfall of Austria's economic performance and especially its total factor productivity (TFP) growth compared to former periods and the concomitant increase in several other OECD countries, especially the Nordic countries, put issues of growth and how to foster TFP growth high on the agenda of economic and innovation policy (GNAN, JANGER \& SCHARLER 2004; Leo et al. 2006). According to new endogenous growth theory, new economic geography and innovation theory, highly-skilled individuals are one of the key factors impelling innovation and knowledge driven economic de-

\footnotetext{
1) Research for this paper was a part of the research project DYNREG, funded by the European Community's $6^{\text {th }}$ Framework Programme.
} 
velopment (LuCAs 1988; Romer 1990; Krugman 1991; Sterlacchini 2008; ZuCKer \& DARBY 2007). Additionally, a recent survey of multinational enterprises' perception of locational factors for headquarters in Austria found out that the availability of a highly-skilled workforce and the educational level are among the most important locational factors and of increasing importance (SIEBER 2008). Taken together, the ascent of knowledge-based economies and the "brain power society" (FUJITA 2007) increase the need for talented individuals in general, not only for high-tech industries but in all sectors of the economy; it is expected that this trend will continue and presumably accelerate in the future.

Talented individuals have become more and more mobile over the last decades, while the mobility patterns resemble more and more that of short-term circulation instead of long-term migration. They transfer valuable knowledge from one region, sector or firm to another ("the best tech-transfer is a pair of shoes") and contribute to the upgrading of regional knowledge pools by means of their mobility, triggering positive static and dynamic externalities (DörRING \& Schnellenbach 2006). Hence, locational competition for talent has sharply increased during the last decade (OECD 2009; ILO 2006; SIEBERT 2006). In other words: "The main issue is how to capture the geographically localised positive knowledge externalities of skilled people" (STRAUBHAAR 2001, p. 222). I refer to this new type of policy as Brain Competition Policy $(\mathrm{BCP})$, defined as the attraction, retention, education, circulation and utilisation of talent functioning as knowledge spillover agents in and between regional, national and supranational economies. In the following, I denote BCP actions targeting the population residing inside the jurisdiction as internal $\mathrm{BCP}$ and the respective actions for talent residing abroad as external $\mathrm{BCP}$ (for an overview of strategies for external BCP conf. Appendix B).

Generally, however, the interests of policy makers between competing regions and countries are exactly the opposite: While regions generally gain economically from out-migration of underemployed or unemployed low-skilled population, they suffer, at least initially, from the exit of highly-skilled population (WEIZSÄCKER 2008a, 2008b). Nevertheless, it is one of the major findings of recent regional policy, innovation and mobility research, that there exists no simple dichotomy between brain gain and brain drain, questioning the classical view of MYRDAL and other scholars of cumulative causation at least for the mobility of highly-skilled individuals (S AXENIAN 2006; GäCHTER 2006). Due to the existence of knowledge spillover agents and other associated positive effects which might accrue because of the existence of a highly-skilled diaspora, the outcome of locational competition for talent is not necessarily a zero or even negative sum. Clearly, a crucial factor securing positive-sum outcomes between regions is a set of coherent and coordinated policy measures. Consequently, more complex patterns of mobility and knowledge flows raise the need for more differentiated and complex policy measures (see Appendix B).

Given the high and increasing importance of a highly-skilled workforce, documented for the case of Austria for example by the increasing output elasticity of R\&D researchers (FAlK \& HaKe 2008; see also Gnan, JANGer \& Scharler 2004), i.e. the change in output due to an 1\% increase in R\&D workers (1980-2005: 0.15\%; 1985-2005: 0.21\%; 1990-2005: 0.26\%), the question arises how Austria performs in the competition for 


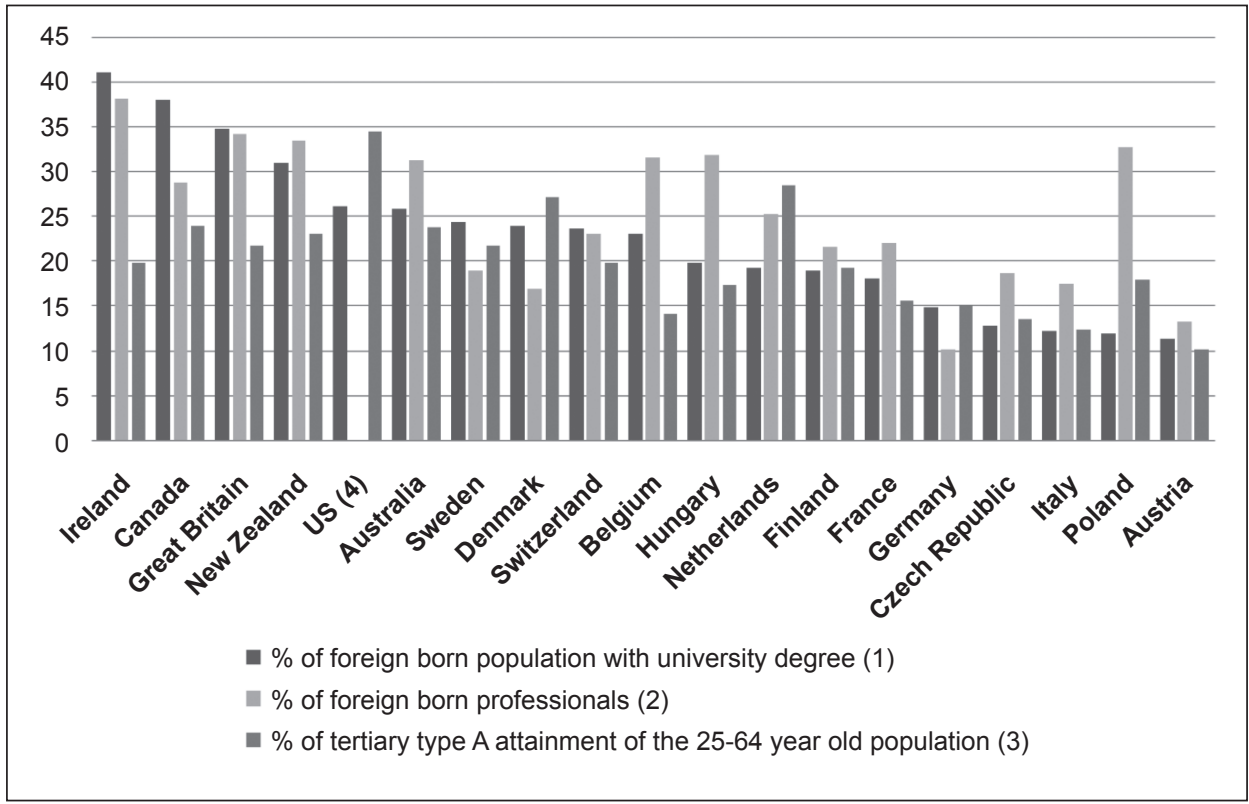

Data: OECD 2008a, OECD 2008b

Fig. 1: Highly-skilled human capital of the foreign-born population and of the total population, sorted downward by $\%$ of foreign born population with university degree

(1) in \% of total students; (2) employees under the ISCO classification for occupations in group 1 (jobs with management competence) and 2 (scientists); (3) tertiary type A programs are largely theory-based and designed to provide qualifications for access to advanced research programs and professions with high-skill requirements; (4) \% of foreign professionals is not available for the US.

talent. Figure 1 shows an unambiguous picture: Austria displays the lowest share of foreigners with a university degree among all OECD countries. Additionally, also the share of foreign professionals is one of the lowest of all OECD countries. This points to a rather weak competitiveness in attracting foreign highly-skilled individuals (REINER $2008 \mathrm{~b}$ ). However, even the overall share of the population having received a tertiary education is very low, inter alia because of a long dominating elitist university model (BIFFL 2004). Furthermore, the small proportion of workforce with a tertiary education leads to very high returns for the highly skilled on their human capital investment and hence a remarkable income inequality, verifying the scarcity of university graduates in Austria (OECD 2008a). Taken together, this unfavourable endowment with human capital may act as a serious bottleneck for improved growth prospects for the Austrian economy (Aiginger 2004; GnAN, JANGer \& SCharler 2004).

As a consequence of the unfavourable situation shown in Figure 1 and the generally increasing importance of national and global human capital, there is hardly any current sectorial or territorial innovation strategy without some recommendations to 
increase the attraction of talent (for Austria see Appendix A; MAHROum 2005; ILO 2006; OECD 2009). One of the main driving forces behind this new orientation of regional and innovation policy on human capital issues are the recommendations of the Lisbon Council in 2000. Accordingly, the European Union (EU) and its member states should set policy actions " $\ldots$ to attract and retain high-quality research talent in Europe" (European UnION 2000). The program of the current Austrian coalition government (ÖSTERREICHISCHE BUNDESREGIERUNG 2008, p. 44) makes a similar point: "To achieve a frontrunner position in research, Austria has to attract the best brains for R\&D." A recently conducted policy analysis by the author for Austria reveals that also nearly every regional government at the NUTS-2 level, i.e. the so-called "Länder", has put in place some BCP. For example, the innovation strategy of Upper Austria [Oberösterreich] declares the "recruitment of foreign engineers facilitated due to cooperation with its neighbouring regions in Germany and the Czech Republic" (LAND OBERÖSTERREICH 2005, p. 57) as a policy measure to secure the sufficient supply of a highly-skilled workforce. Another example may be given from a study for regional innovation policy in Tyrol [Tirol]: "Nothing is more important than to attract foreign talent to Tyrol - [...] students, researchers, managers and entrepreneurs" (Tiroler ZuKunftsstiftung 2007, p. 93). Taken together, this leads to a highly complex policy fabric due to policy initiatives implemented at different spatial scales under the framework of multi-level governance in the EU.

The aim of this article is to investigate the preconditions and prospects of the Austrian economy in the competition for talent or in other words, to become a "sticky place" (MARKUSEN 1996) for home-grown and imported highly-skilled individuals, based on the framework of BCP. By talent or highly-skilled workers I understand university-educated managers, engineers, scientists and students, assuming that these are the most relevant target groups for Austrian BCP. As a starting point we have to think about the main factors determining flows and stocks of highly-skilled workers. While the mobility behaviour of talent is complex in nature, it seems reasonable to distinguish between four broad categories: (1) institutions, i.e. history and culture, (2) industrial structure, (3) scientific performance and (4) migration and labour market regulations. Traditionally, the focus of related studies is heavily biased towards migration regimes. Indeed, the regulation of immigration via a point-based system might be of high importance for the good record of countries like Canada or Australia in the attraction of the highly skilled (see Fig. 1). However, the article concentrates on the factors (2) and (3) while also taking into account intuitional factors, especially effects of path-dependency. This is justified by several reasons. First, there are already a number of studies on the effects of migration rules on highly-skilled mobility (OECD 2009; WeIZSÄCKER 2008a, for a documentation of the respective regulation in Austria see BMI 2008). Second, a large share of the relevant mobile population stems from EU countries. Hence, this population can - sooner or later - circulate inside the EU without any restrictions (Tichy 2008; Bock-Schappelwein et al. 2009). Third, the relative decrease of the importance of migration rules compared to other factors for shaping highly-skilled flows is a global phenomenon because of the convergence of migration rules as a consequence of policy spill-overs: While the migration rules for the low-skilled are characterised by a race to the top, those for the highly skilled 
are dominated by a race to the bottom (BOERI \& BRÜCKNER 2005). Due to the relative equalisation in migration rules, industrial structure and scientific performance gain importance (one might compare the outcome with the effects of the abolition of national exchange rate policies between the countries of the Euro area). Taking into account that especially industrial dynamics are highly localised phenomena, the regional level may become more important in shaping flows of highly-skilled workers, e.g. via cluster policies (FromHold-EISEBITH 2002).

The paper is organised as follows. Section two investigates the structural preconditions resulting from the status of Austria as a small open economy. The section identifies four generic stylised facts emphasising the relatively higher importance of BCP for small open economies than for large economies like Germany or the US. Sections 3 and 4 are devoted to the specific conditions of the Austrian business and university sector illustrated by two paradoxes, the "Austrian Paradox" and the "European Paradox". Both sectors provide, generally speaking, no advantageous position on the increasingly competitive market for talent. Section 5 concludes with some policy considerations.

\section{Country size matters! The case of small open economies}

One of the most prominent features of the Austrian economy is its relative smallness. The size of a country, measured by population or GDP has been an important variable in different economic theories (Alesina 2003). In a narrow sense, the term "small open economy" refers to a specific type of international macroeconomic modelling, specified by a completely elastic net capital export function at the level of the global interest rate (KRUGMAN \& OBSTFELD 2009). However, I understand the term in a more generic sense, as a simple definition of relatively small countries measured by population size compared to other states. The aim of this chapter is to describe and examine four stylised facts associated with country size and BCP. The main argument is that all these facts point to the higher importance of BCP for small states compared to large countries. It is noteworthy that the mentioned stylised facts need to be understood as ceteris paribus propositions.

\subsection{Stylised fact 1: Small states are very open economies}

This stylised fact holds for product and factor markets as well as regarding innovation activities (OECD 2008c). Indeed, Austria is one of the most open economies in Europe. In particular, openness surged dramatically after the opening of Eastern European markets around 1990 (AIGINGER 2008). A recent study also reports a sharp increase of intrafirm trade as a result of slicing up the value chain and a change in company-wide divisions of labour due to large-scale offshoring and outsourcing of production steps by Austrian firms to Eastern European countries (MARIN 2008). Despite the prevailing public opinion that the single motivation behind this spatial spread 
of firm boundaries lies in cost-cutting, MARIN (2008) stresses a second cause: Firms take advantage of the pool of skilled workers available in the new EU member states (EDERER, SCHULLER \& Willms 2007). Increased openness, either because of intrafirm or interfirm trade, is a result of specialisation and economies of scale. Productivity and growth of small countries would be much smaller if the market size concurred with the political size (AlESINA 2003). In a dynamic perspective, this explanation can be justified by learning effects and the related model of the learning curve: Higher (cumulative) output triggers lower unit costs because learning and experience increase with the output (KRUGman \& OBSTFELd 2009). Hence, small countries are much more dependent on an international division of labour.

A higher degree of openness of imports and exports entails a higher demand for managing transboundary economic transactions (PETHE 2007). Indeed, language skills and knowledge of foreign markets are two of the most important reasons for firms to hire foreign talent (OECD 2009). Despite the already established Single Market for goods, barriers still exist. One powerful barrier is built up by different languages and institutions. For example, SAUTER (2009) tested the impact of different languages on trade volume between different Canadian regions. The reported results are interesting, given the otherwise common institutional context of the Canadian state, which does not exist for the trade exchanges between Austria and its export markets: "Trade in industries with a need to communicate directly (orally) with importers increases with the probability that people in another province speak the same language" (SAUTER 2009, p. 2). Accordingly, small countries have a relatively higher demand for managers with the ability to govern processes of corporate internationalisation. Firms faced with a high diversity of customers and other stakeholders may benefit from reflecting this diversity in their workforce (FISCHER 2008). Since language proficiency and institutional knowledge may be of critical importance, hiring foreign highly-skilled workers with the respective competences seems to be quite important for small open economies like Austria. Small countries like Sweden, the Netherlands or Ireland already invest heavily in more internationalised human capital to cope with the growing internationalisation of their business sector (MAHROUM 1999). There is anecdotal evidence for the lack of an adequate response of the Austrian education system given the stressed internationalisation patterns. There seems to be, for instance, some reluctance to teach and learn Slavonic languages at school and even at university, too. More importantly, the cultural and language skills of immigrants provide quite valuable resources for managing trade and outsourcing issues. However, the Austrian system of integration has failed to enable the utilisation of these resources in an efficient way for decades (HAAs 2008). According to Aiginger (2008), a successful attraction and education of foreign highly-skilled students may boost Austrian exports, functioning as "market openers" in their respective source regions and countries (for a related argument on the role of US-educated foreign students see STRAUBHAAR 2000). Empirical support for the importance of this argument is given by the fact that information deficits are the main obstacles for export-business of European SMEs (Deutsche B ANK ResEARCh 2009).

Small economies are generally more dependent on cross-border R\&D co-operations (OECD 2008c). R\&D co-operations are presumably more complex than trade in goods and services. Strong cultural and institutional distances are potentially quite important 
factors inhibiting transnational innovation activities of firms and research institutions (TRIPPL 2006). Again, the need for scientists and engineers qualified to conduct such complex "bridging" tasks arises. Empirics for Austria reveal a mixed picture: While the share of patenting firms with foreign co-inventors is above the OECD average, the percentage of firms collaborating in $\mathrm{R} \& \mathrm{D}$ with non-European economic actors is below OECD average and comparable to countries such as Sweden, Denmark, Finland or the Netherlands (OECD 2008c; OECD 2008d). This may reflect the still quite successful integration in European and especially German innovation networks and an industry structure relying more on a synthetic than on an analytical knowledge base (AsHEIM \& GeRTLER 2004) as well as a general preference of companies to collaborate with innovation partners which are geographically close. Yet, the ever increasing importance of growth markets outside Europe (AIGINGER 2008) as well as of gaining access to valuable non-European knowledge pools may point to the need to attract foreign highly-skilled workers capable of rendering and facilitating more globalised R\&D collaborations and global knowledge pipelines. Furthermore, given the predominance of the US and some other non-European countries in high-tech sectors, tapping into these cutting-edge knowledge pools may require the setup of R\&D networks with non-European high-tech clusters (conf. also the current Austrian government program, ÖSterReichische BundesRegierung 2008).

\subsection{Stylised fact 2: Small states have higher rates of brain drain}

Labour markets for highly-skilled labour are characterised by an ongoing rise of openness and fluctuation (MANPOWER 2008; OECD 2009). This leads to higher rates of brain drain for small states compared to large states (BeIne, DocQuiER \& SchifF 2008). Even though this finding was first observed in developing countries, it holds also for OECD countries (see Fig. 2 and 3). In this sense, the rather high rate of $9.8 \%$ of Austrian university graduates staying abroad is in line with comparable countries like Switzerland, which exhibits exactly the same rate (OECD 2008b). For comparison: $7.1 \%$ of German, $4.2 \%$ of French and $0.4 \%$ of US university graduates reside in foreign countries. Even though the rate of $9.8 \%$ is still high, an earlier study by DocQUiER $\&$ Marfouk (2006) reports a rate of $18.3 \%$ for the 1990 s, which clearly indicates an improvement of Austria's brain drain rate during the last years.

Explaining the empirical regularity shown in Figures 2 and 3 proves to be more complicated than it is for product markets. One possible explanation refers to the observation that small countries show systematically different education and research policies, which both contributes to higher rates of out-migration. NERDRUJM \& SARPEBAKKEN (2006) claim that small states predominantly follow an "internationalistic research policy approach", thereby increasing temporary or permanent brain drain. This should enable small countries to benefit from foreign R\&D investments, e.g. by learning from foreign researchers due to a sabbatical for senior researchers or a study sojourn for students. Especially the Nordic countries encourage their scientists and $\mathrm{PhD}$ students to go abroad in order to internationalise their national innovation system (NERdRujm \& Sarpebakken 2006). Another argument refers to the possible yearning 
of the populations of small countries to gain some experience in foreign states. For example, young New Zealanders have always been very mobile in order to achieve so called "overseas experiences" (DAVENPORT 2004).

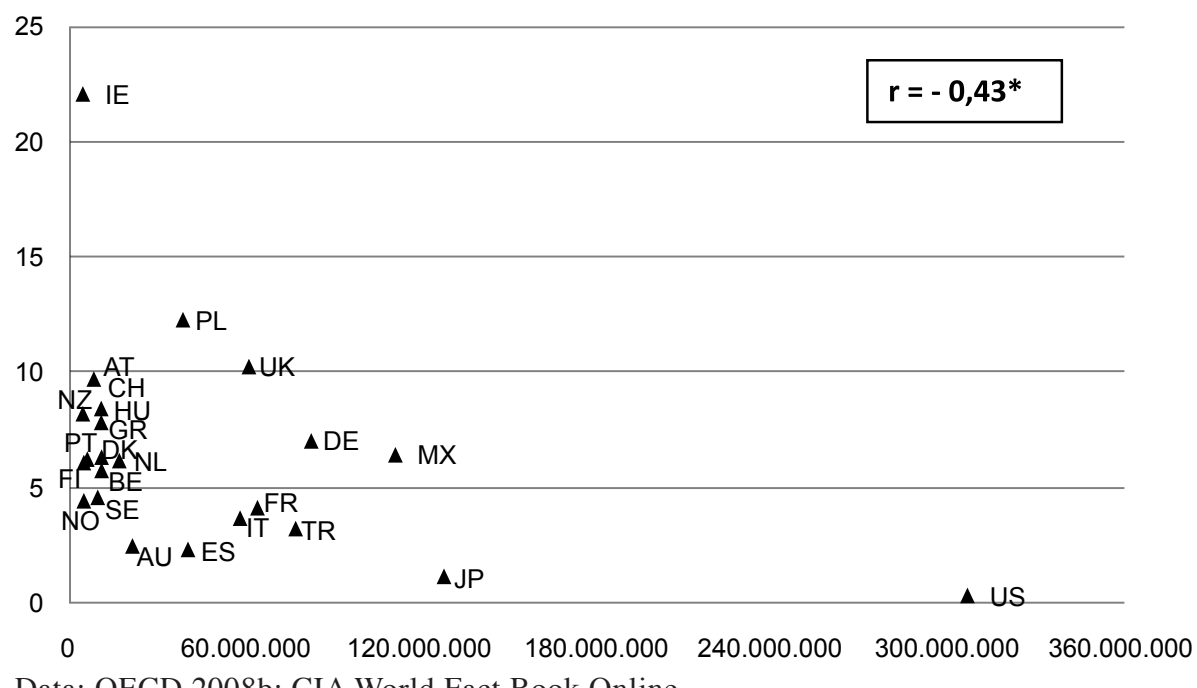

Data: OECD 2008b; CIA World Fact Book Online

Fig. 2: Country size (population in millions) and emigration rate of native university graduates in OECD countries $(n=24) .-*$ significant at the 0.05 level

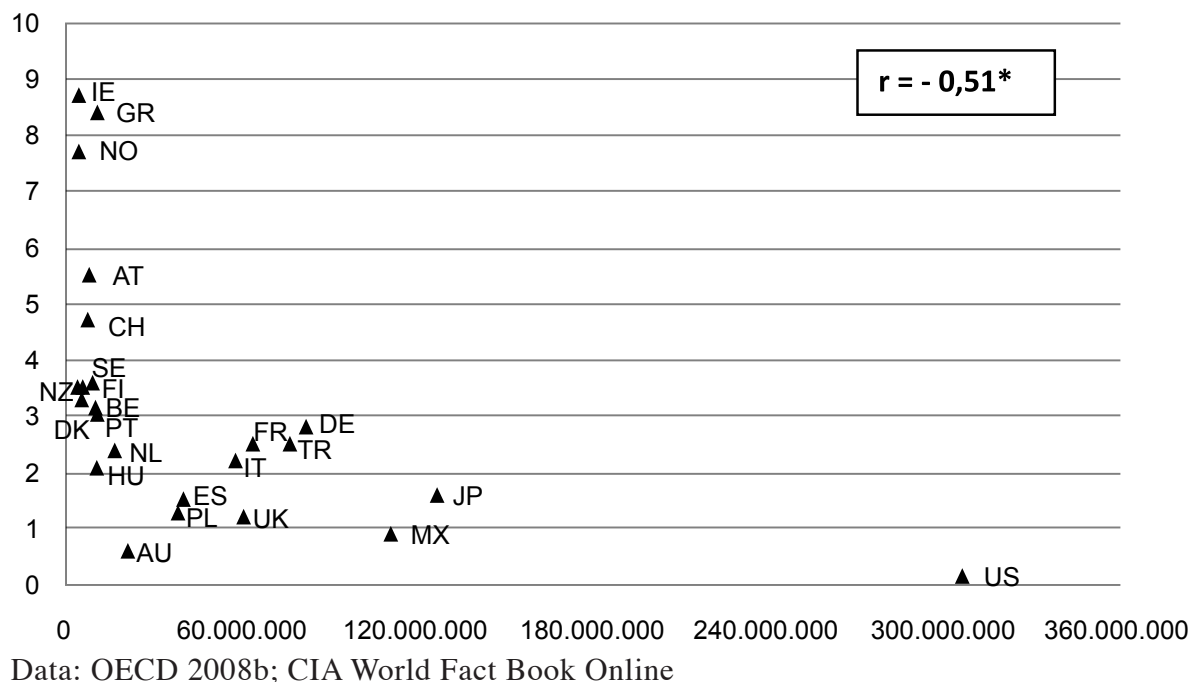

Fig. 3: Country size (in millions) and tertiary students abroad (in $\%$ of the total number of national tertiary students) in OECD countries $(n=24) .-*$ significant at the 0,05 level 
A high proportion of national talent residing abroad, i.e. a relatively huge highlyskilled diaspora, points to the need of diaspora policies to harness these valuable resources in situ. Otherwise, the brain drain will trigger all negative impacts which are typically associated with the outflow of the national elite. A case study from DAvenPORT (2004) on brain drain from New Zealanders to foreign countries demonstrates an ideal-type sequence of policy actions. After a "moral panic" over a (wrongly) perceived large outflow of highly-skilled New Zealanders, the government introduced policy actions to control the individual behaviour of the highly skilled, either by immediate restriction or by taxation to mitigate negative fiscal externalities. This phase is denoted as "control phase". Despite the possible (national) public appeal of such policy actions, they do not appear to have been successful neither in practice nor in theory (DAVENPORT 2004). Nevertheless, there are still some politicians following this approach. For instance, a member of the Austrian Social Democratic Party suggested in a recent interview concerning the release of a new economic policy program of the Party in 2009, that it would be necessary to implement "protective mechanisms in order to impede out-migration of costly-educated highly-skilled workers. We should not shy away from protectionist measures" (DIE FuRCHE, 16. April 2009, p. 5, translated by the author). However, in a second phase, the New Zealand government introduced quite a different and much more systemic policy approach. This so-called "stimulation phase" was dominated by a positive perception of the presence of a national diaspora. The introduced policy measures aimed at (re-)connecting and thereby harnessing the diaspora with national and regional innovation systems (MAHROUM 2005). In other words: "Policies to activate the diaspora of scientists and technologists, in order to build research capacity and excellence, result in reframing of the national STHC (scientific and human technical capital) base that is no longer circumscribed by a geographic boundary. That is, a nation's human capital stocks are perceived as a global network of culturally affiliated skills, defined by country of origin rather than country of residence" (DAVENPORT 2004, p. 629).

Even in the case of permanent migration, there are possibilities of knowledge transfer. Based on "enduring social relationships" (Agrawal, Cockburn \& McHale 2009) between the national scientific community and the scientific national diaspora, epistemic networks may emerge, enabling and facilitating the diffusion and spillover of tacit knowledge. Social, organisational and institutional proximity are powerful substitutes for spatial proximity, bridging spatial distance by means of Information and Communication Technologies (ICT) and other forms of virtual mobility like video conferencing (Boschma 2005, EC 2008). Nevertheless, the diaspora approach has some caveats. If the cited forms of proximity are missing, for example as in the case of science-industry cooperation, spatial distance may inhibit successful joint research projects. Furthermore, diaspora talent will be willing to stay in contact with the national scientific community only under certain conditions. Probably the most important one is a good research performance so that even the diaspora scientist can benefit from transnational cooperation. Additionally, given the aim of the diaspora policy to benefit from diaspora externalities, this proves to be another necessary precondition since these externalities may only accrue to the home region if it has an adequate absorptive capacity. Absorptive capacity, in turn, consists inter alia of a well performing scientific system. 


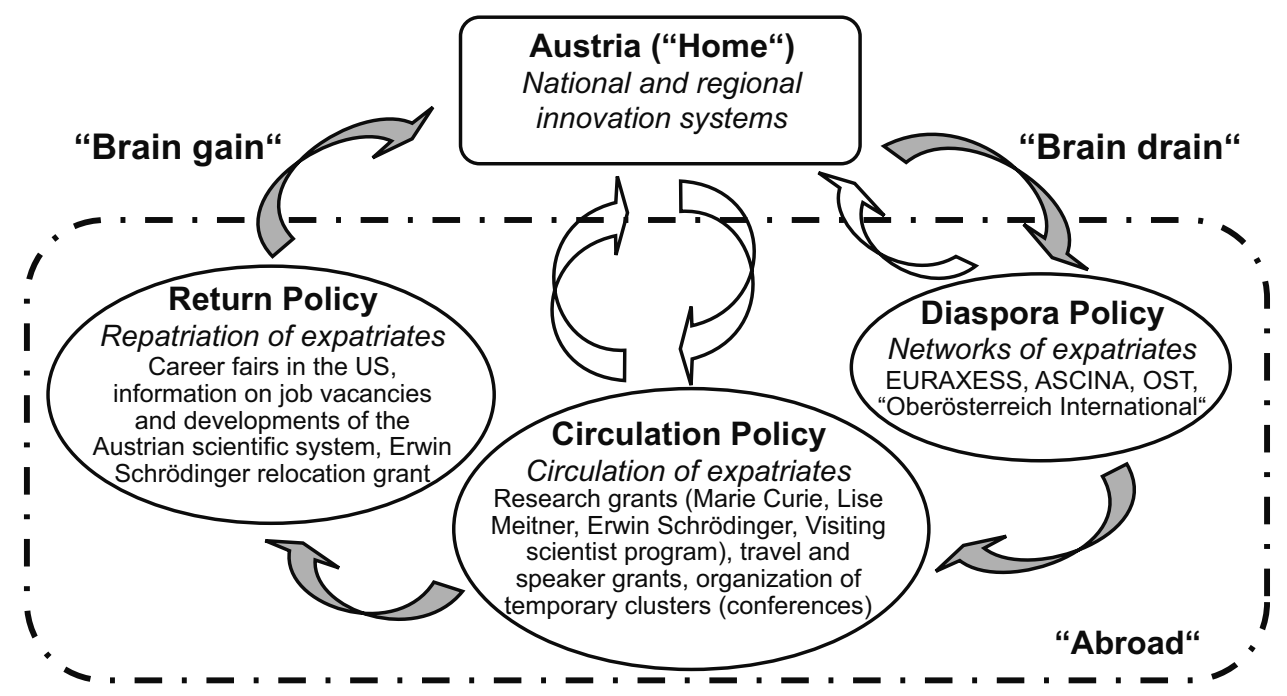

Fig. 4: How to harness the Austrian diaspora?

From a dynamic and systemic perspective diaspora policies may be part of a more holistic strategy. The idea behind this approach is the following (see Fig. 4): After the talented national individuals have received valuable foreign knowledge, they should be motivated to return back home or to circulate between the home region and abroad so that the home region can benefit from knowledge spillovers (LoDigIANI 2008; SAXENIAN 2006). To achieve this sharing of benefits between different regions, maintaining communication and staying in contact with the diaspora are crucial factors for success. In addition to diaspora policies, circulation policies further contribute to maintain or even intensify social and epistemic networks between the home region and the diaspora (see Appendix B). All in all, this leads to an increased probability of return at a later point in time, provided that there exist appropriate career opportunities, up-to-date research equipment and a well-endowed research staff. Figure 4 shows these steps for the case of Austria together with some policy instruments at the regional, national and European level.

A number of Austrian elite researchers made important scientific experiences abroad, before they returned back home - acting as knowledge spillover agents - with new and up-to-date knowledge and social linkages to foreign scientific communities, not available to the national scientific system before. For instance, the directors of two of the most important Austrian research organisations, IMBA (Institute of Molecular Biotechnology) and ISTA (Institute of Science and Technology Austria), Josef Penninger and Thomas Henzinger, held a chair for their respective field of study at the University of Toronto and the University of California in Berkeley, respectively, before they returned to Austria and took over the leadership of newly established national research organisations. However, given the circumstances of the Austrian university system, it is anything but easy to re-enter, even and maybe especially if the foreign knowledge is at least partially superior compared to that of the home-based research- 
ers (Morano-FoAdi 2005). For example, as a consequence of these difficulties, the Erwin Schrödinger scholarship holders have - since 2009 - the possibility to apply for a special return grant after they have stayed abroad for about two years. Taken together, small states like Austria have a relatively larger diaspora. As a consequence, diaspora and circulation policies are more important for them than for large countries with a relatively small diaspora. However, even if Figure 4 suggests a comprehensive Austrian policy framework, this is clearly not the case. The figure only provides an overview of what is going on; the relevant arrows which point to reconnection and coordination issues are still underdeveloped in reality (HAAs 2008; OECD 2009).

\subsection{Stylised fact 3: Small states feature a narrow labour market}

Third, small states naturally have a small labour market. The relevance of the labour market size stems from the labour market pooling argument. KRUGMAN (1991) demonstrated that one of the main factors making pooling beneficial is the uncertainty of the economic agents. Highly-skilled workers entering a new labour market with a limited amount of information are faced with uncertain economic prospects (SIEBERT 1995). Taking risk aversion into account, individuals benefit from the existence of larger labour markets since they can diversify their risk of getting unemployed through facilitated employer-employee matching. In other words: "The larger the labour market to which an immigration permit offers access, and the more permanent this access is, the more attractive the destination is for high-skill immigrants" (WEIZSÄCKER 2008a, p. 3). A related statement can be made about the market position of the EU (and Austria) on the global market for higher education; here the multilingual patchwork of languages and higher education systems limit the attractiveness compared to other countries, especially the US (EC 2008; ZimMERMANN 2008). However, the small size of labour markets can be offset by regional integration.

Nevertheless, there still exist major impediments for the successful attraction of non-EU highly-skilled workers (EC 2008). They are not entitled to move freely within the EU once they have legally entered the labour market of one EU country. Given the brain drain of European talent to the US and the lack of attractiveness for foreign talent, the EU Commission tried to change this unfavourable position of Europe by introducing the so-called "blue card", to attract non-EU talent (TRIDAT 2008; WEIZSÄCKER 2008b). Despite the resemblance to the US "green card", they are quite different. The major distinction lies in the fact that the blue card only offers a temporary residence permit while the green card provides immigrants with a permanent one - a clear comparative disadvantage of the blue card. Nevertheless, it seemed to be an improvement since the blue card was thought to open the entire EU labour market by granting the portability of immigrant status across national borders between the EU member states. Alas, national resentments prevailed and a number of EU countries toppled this main advantage of the blue card. As a result, the much larger integrated US labour market still offers much more opportunities and thus risk diversification potential than the strongly segmented European labour market. One of the main countries prohibiting the enactment of the blue card was Austria. This is at least curious, given that Austria 
as a small country has much more to gain from the widening of the labour market as a compensation for its relatively small labour market than a number of other EU countries. So far, there seems to be no alternative solution to the blue card. Generally, an economic union like the EU suffers in efficiency and growth from the presence of national migration policies (ZIMMERMANN 2008). The brain drain from the EU and also from Austria to the US can be reduced only if respective measures are taken also at the European level (BIFFL 2007).

Taking the Lisbon strategy seriously, it is of utmost importance to speed up the integration of the EU labour markets for the highly skilled. One current EU project is the establishment of the European Research Area (ERA), a single labour market for researchers. The aims of the ERA can be summarised as "attraction, ethical recruitment and retention of researchers" (EC 2008, p. 18). Again, Austria is potentially one of the main beneficiaries by substituting an EU-wide ERA for its narrow research labour market. Yet, even if Austria - like other small countries - has much to gain from labour market integration, it exerts political opposition on the EU level, thereby deteriorating its position in the locational competition for talent. Taking economic efficiency as a yardstick, this is the contrary of what can be expected from policy agents of a small country like Austria.

\subsection{Stylised fact 4: Small states lack national multinational enterprises}

Fourth, small countries seldom have home-grown multinational enterprises (MNEs). The corporate sector is dominated by small and medium enterprises (SMEs) (DEUTSCHE BANK RESEARCH 2009). This may be a consequence of the market size, whereby big home markets support the emergence of MNEs, and of differences in resources available for industrial policy to promote "national" champions with global importance (e.g., the defence industry in the US or the duopoly of Airbus and Boeing) and in political power. Figure 5 shows this stylised fact by using the number of firms listed in the Global Fortune 500 ranking according to their home country as a proxy for MNEs. Excluded from this country selection were all newly industrialising and transformation countries and especially the BRIC (fast-growing economies of Brazil, Russia, India and China) countries. The 20 countries included represent 394 out of 500 firms.

SMEs face specific problems regarding invention and innovation (MAYER \& BLAAS 2002). A crucial factor is their quite different position on the labour market. Faced with increased "recruitment-based competition" for talent, multinational firms can tap foreign intra-firm and extra-firm talent pools in two ways which are not available to SMEs: Either they hire foreign talent abroad for a foreign subsidiary, e.g., a regional headquarter or research centre, or through their internal and often globalised labour market. Especially the latter gives MNEs (larger states) a comparative advantage over SMEs (smaller states) in attracting foreign talent. Hence, the possibilities of SMEs to acquire new knowledge through "learning by hiring" are systematically constrained. Contrary to MNEs, they generally have a much lower degree of popularity which additionally hampers talent attraction (REINSTALLER \& UNTERLASS 2008). Their ability to pay higher wages is restricted and globalised internal labour markets are absent. The 


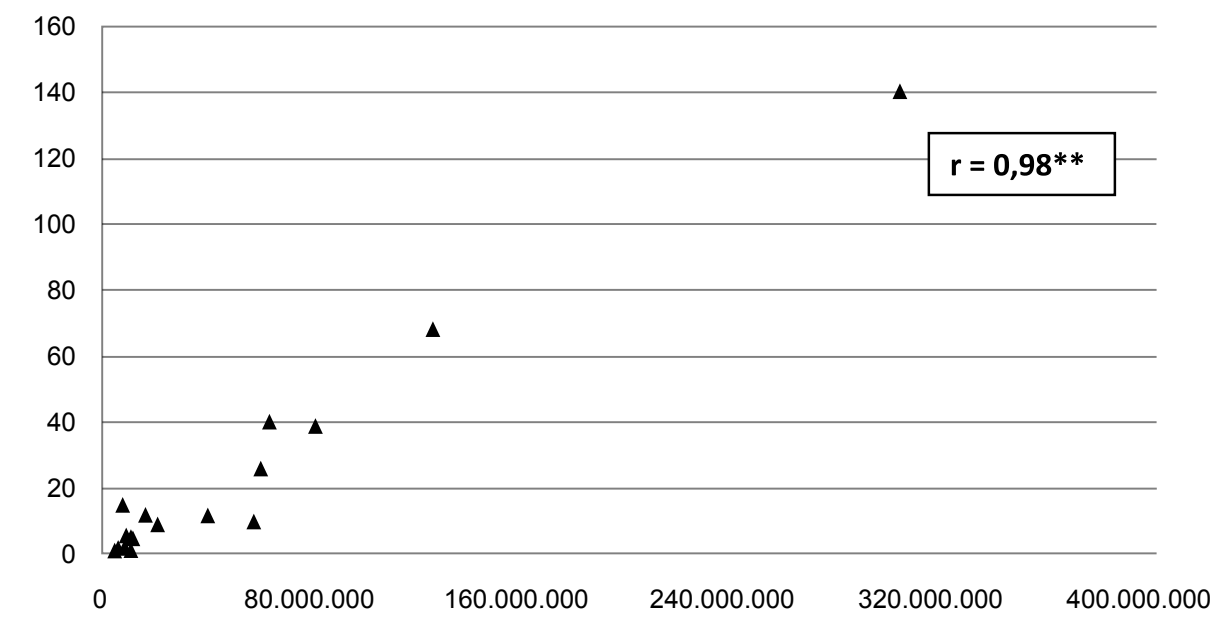

Data: Global Fortune 500 (2009); CIA World Fact Book Online

Fig. 5: Country size (in millions) and number of firms ranked in the Global Fortune 500 per home country in OECD countries $(n=20)$. - ** significant at the 0,01 level

restricted payment ability of SMEs proves to be an even more severe disadvantage in the age of accelerated globalisation which triggers unprecedented rises of executive payments not at least as a consequence of a battle for talent (MARIN 2009). Since small states like Austria depend on a SME-dominated firm structure, policy actions may be considered to mitigate this structurally-induced shortfall.

A good example in this respect was the introduction of the German green card, a temporary work permit for non-EU ICT professionals. Similar to the stipulation of the quotas for ICT professionals under the US H1B visa, the introduction of the German green card was pushed forward by strong interest group pleading - before the new economy bubble burst - from employer associations. The number of actual immigrants was much lower than expected and the green card initiative was denounced as a failure. However, looking a bit more closely at what happened, it becomes clear that it was at least partly the missing demand of the big firms which hampered higher immigration numbers of ICT professionals. They have already established their own mechanisms and channels for the recruitment of foreign talent; flows of intra-firm transferees secure their efficient spatial allocation between the multiple locations of the MNEs. As a result, during the four year period in which foreign IT specialists could immigrate under the "green card" regulation, 75\% of IT-workers were hired mostly by SMEs. Taken together, this is an impressive result pointing to the heavy reliance of SMEs on policy support via BCP in their recruitment of foreign talent (KolB 2005). Empirical studies provide clear evidence that the undersupply of highly skilled people is the main obstacle for expansion in fast growing SMEs (REINSTALLER \& UNTERLASS 2008). Taken together, small states and their regions have a higher need for BCP than big states with a number of MNEs. It may be misleading, especially from a regional 
policy point of view, to confine support for SMEs' recruitment activities to various immigration laws. For instance, Vorarlberg, a highly industrialised Austrian province, is taking a number of place branding measures thereby supporting the limited possibilities of employer branding by SMEs by, e.g., joining career fairs at technical universities in Germany or Switzerland whose graduates meet the differentiated needs of the regional labour market. Such initiatives are quite reasonable, since a single SME has neither the resources nor the incentives to organise place marketing actions because of positive externalities on which other firms can economise without bearing the costs.

\section{The Austrian paradox and the business sector}

Mobility of talent and human capital investment patterns are heavily shaped by economic and scientific performance as well as by industrial structure which are in turn influenced by political and economical history so that path dependency plays a crucial role. Taking these propositions seriously, an investigation of the Austrian scientific and business sector is needed, which pertains their push and pull forces of shaping mobility and human capital investment of the highly-skilled. One possible way to do this is to take two frequently discussed paradoxes of the Austrian economy as a starting point.

Several scholars denoted the Austrian growth-path as paradoxical, or to be more specific as the "Austrian paradox" (Peneder 1999, 2008). Economic structure and growth-performance seem to be partially decoupled, which leads to explanation difficulties by conventional economic reasoning on economic growth (e.g. Romer 1990). Another paradox is the so called "European paradox", which denotes a proposed superior scientific performance of the European scientific system with a concomitantly inferior position in patenting and innovation compared to the US as a result of weak university-industry linkages (Dosi, Llerena \& Sylos Labini 2005). While the following chapter discusses the "Austrian paradox", the Austrian "European paradox" and its ramifications for BCP are analysed in Chapter 4.

Based on the assumptions of SCHUMPETERerian economics, industrial structure and economic performance, i.e. economic growth, are interdependent phenomena. A higher proportion of innovative branches will shift the economy to a higher growth path. However, Austria provides a growth puzzle or paradox, given these theoretical assumptions. Following PENEDER (1999, p. 239), the Austrian paradox can be summarised as follows: "On the one hand, macroeconomic indicators of productivity, growth employment and foreign direct investment show that overall performance is stable and highly competitive. On the other hand, an international comparison of industrial structures reveals a wide gap in the most technologically-advanced branches of manufacturing, suggesting that Austria has problems to establish a foothold in the dynamic markets of the future." The potential threat of the traditional Austrian economic development path lies in the fact that especially the new European member states, like the Austrian neighbouring states of the Czech Republic or Slovakia, have 
quite similar factor endowments and comparative advantages (TICHY 2007; GASSLER \& Nones 2008). Given the still lower wage levels, they may crowd out Austria's export industries on international markets in the field of advanced middle-technology goods. A recent update and evaluation of the Austrian paradox hypothesis demonstrated that the predictions were generally correct, but also that a possible solution is under way (Peneder 2008): On the one hand, Austria's GDP growth diminished in the last decade, compared to past growth rates and, what is even more important, to the Nordic countries and the US, demonstrating the ongoing growth possibilities of rich countries. On the other hand, an upgrading of the industrial structure towards a broadening of innovation intensive industries is taking place, thereby reconnecting structure and wealth according to theoretical assumptions: Rich countries need high-tech industries to stay competitive under globalisation characterised by an accelerated abolishment of market segmentations and hence a strongly increased competition on factor and product markets (AUDRETSCH 2001; REINER 2008a).

\subsection{Emerging high-tech industries}

The literature on the Austrian paradox argues that Austria's competitiveness has to be maintained by fostering structural change and upgrading of the industrial base towards increased technology intensity. Austria's existing albeit relative small hightech sector is dominated by foreign-owned firms. In accordance with the overall high degree of openness and internationalisation of the Austrian economy, even R\&D activities are heavily internationalised: Austria displays the highest share of foreign R\&D financing of all OECD countries (GASSLER \& NONES 2008). The majority of these funds comes from a relatively small number of foreign MNEs. However, R\&D activities of these MNEs in Austria are mainly based on adapting existing technologies to (Eastern) European markets instead of undertaking cutting-edge research, which inhibits more valuable knowledge spill-overs to Austrian firms and employees (TicHY 2007).

Numerous implications for BCP arise from these structural findings. First, considering external $\mathrm{BCP}$, a rather small number of high-tech firms and clusters reduces agglomeration forces and demand which might pull foreign highly-skilled workers to Austria. This result can be interpreted similarly to the level of the R\&D quotas: The long-lasting low level of R\&D expenditures reflects the predominance of nonhigh-tech industries (GNAN, JANGER \& SCHARLER 2004; TiCHY 2007); the low level of foreign highly-skilled workers reflects - inter alia - the rather low demand for those skills which simply do not fit the predominant industrial structure. However, even the existing high-tech branches and clusters lack international visibility: Austria is not perceived as a location for high-tech industry (HAAs 2008). Accordingly, the high level of low-skilled immigrants and the low level of foreign born highly-skilled individuals reflect a long dominating rather low-road strategy of the Austrian manufacturing sector as well as its big tourism sector. This static model of competition is based on low-skilled and low-cost immigrants, subsidising low-cost industries and reducing pressures for innovation. Together with a predominance of cost-cutting strategies like wage-moderation and labour market flexibilisation, the danger of entering a 
low ware trap persists (TICHY 2007). However, immigration policy has changed only recently with the lowering of barriers for the highly skilled and the establishment of additional obstacles for entering the Austrian labour market for low-skilled workers (see Appendix A).

Second, considering internal BCP, the education and university system show some weaknesses for supplying the industry with the needed skills for a high-road strategy because of path-dependency resulting from a dense education sector - industry relationship. During the decades after the Second World War, Austria exploited the "advantages of backwardness" very well. As the economy approaches the technology frontier, a change towards the creation of new knowledge and innovation instead of a simple adoption of foreign produced knowledge is needed. Yet, the educational system and the structure of the human capital accumulated over time still resemble the needs of the catching-up process. Indeed, Austria has founded an excellent equipped educational system based on apprenticeship and a specific secondary school system for technical and (middle) managerial occupations, characterised by the so-called "Höhere Technische Lehranstalten" (HTLs) and "Handelsakademien" (HAKs). Both types suit the traditional predominant patterns of the industrial structure very well. As a consequence, the share of employees having received a tertiary education as well as that of university graduated scientists and engineers are well below the OECD average (BIFFL 2007, TiсHY 2007). However, even if we count graduates from the HAKs and HTLs as tertiary-educated people, which might be a questionable counting methodology, the share of tertiary-educated individuals just reaches the OECD average (JANGER 2009).

Based on econometric studies, it is demonstrated that tertiary education becomes increasingly important as an economy approaches the technology frontier (LEO et al. 2006). One of the main reasons for this are the increasing needs to adapt to the shortened innovation cycles in a fast and flexible manner. The competences for adopting the respective skills are generally better among tertiary-educated employees compared to rather specialised secondary-educated workers. Indeed, some scholars argue that herein lies one of the reasons why EU countries were much slower at adopting ICT, a typical generic technology. Being quite the opposite, the US education system is much more based on the acquisition of general skills with a high degree of tertiary education, facilitating learning and innovation in fast-changing technological environments (Gnan, JANGer \& Scharler 2004).

More importantly, Austria is faced with severe shortages regarding the number of enrolled and graduated scientists and engineers. One of the causes of this undersupply is the natives' lack of motivation to choose science or engineering as their field of study. At least in Austria and Germany, one explanatory factor for this can be found in a suboptimal teaching of these issues at school and a simple lack of information on job opportunities (JANGER 2009). This leads to a stock and growth rate for human resources in science and technology that lies below the OECD average (LEO et al. 2006). Taken together, the Austrian education and university system fails to deliver "home grown" human capital to supplement structural change and TFP growth at the technology frontier (LEO et al. 2006). Path dependency of educational structures produces a possible negative lock-in: "A lack of highly qualified workers in these areas implies that in Austria sectoral specialisation will remain limited to medium technology 
industries" (JANGER \& WAGNER 2004). A lack of human resources with the necessary skills to foster and underpin high-tech driven economic development creates the need to attract these resources from outside the respective region or country. A case study by TRIPPL \& TöDTLING (2007) on the three emerging regional biotechnology clusters in Austria (Vienna [Wien], Styria [Steiermark] and Tyrol) demonstrates the need to recruit and attract foreign talent to develop high-tech clusters in a generally non-high-tech environment in order to overcome associated knowledge gaps which may otherwise prohibit the growth prospects of the biotechnology clusters: "Consequently, the attraction of international scientific and managerial competencies has to be regarded as a key mechanism for the emergence and growth of the Austrian biotechnology sector" (TRIPPL \& TöDTLING 2007, p. 61)

\section{2 "Traditional" advanced middle technology industries}

It would be misleading to denounce the persistent industrial structure as poorly uncompetitive. Indeed, some scholars stress the possibilities of growth and competitiveness even without a predominant high-tech structure (MASKELL 1999). Furthermore, the seemingly one-sided high-tech orientation promoted by the "structural pessimists" is criticised by the "growth optimists" (PENEDER 2008). The latter point to the elusive and fuzzy concepts of technology frontier and "high-tech" in general as well as to the repeatedly verified ability of the Austrian industries to adapt to new competitive market situations even without disruptive change and radical innovation (SCHIBANY 2008). The basis for this ability is made up of a specific production system, once denoted by STREeK (1991) as "diversified quality production" (DQP), consisting of a set of highly specialised industries dominated by incremental innovation and advanced middle-technology products for market niches (Tісну 2007). In the following, these structural aspects are scrutinised to investigate their implications for BCP by applying the knowledge base approach of innovation economics as well as the varieties of capitalism approach of political economy (Maier, KurKa \& Trippl 2007; Asheim \& Gertler 2004; Hall \& Soskice 2001).

According to the knowledge base approach, the core of Austrian industries is predominantly based on a synthetic knowledge base, which, in turn, relies more on tacit than on codified knowledge, the latter being typical for the other ideal type, the socalled analytical knowledge base. The analytical knowledge base comprises roughly all science-based industries like ICT or biotechnology which may build the nucleus even of an emerging Austrian high-tech sector (Asheim \& GerTLER 2004; TRIPPL \& TöDTLing 2007). By contrast, the synthetic knowledge base comprises industries such as plant or mechanical engineering which are typical for the Austrian DQP-mode of production. The argument now is that the interchange of tacit knowledge is generally bound to the spatial co-presence of the economic actors (BERGMAN \& SCHUBERT 2005). Furthermore, without some basic trust between them, knowledge spill-overs may be inhibited (Maskell \& Malmberg 1999). Taking these assumptions as well as the high specialisation into account, it can be argued that an optimal BCP for firms operating 
under the DQP-mode consists of rather long-term mobility patterns, simply because it may take some time until a foreign highly-skilled worker can contribute to the operations of such types of production. Common knowledge, which enables a swift understanding as in analytical-knowledge-based industries, is generally absent since the relevant knowledge mainly stems from experience gained at the workplace (FuJiTA 2007). In other words: "The more dominant tacit knowledge is, the more embedded knowledge creation becomes in local institutions, the more difficult it becomes for outsiders to enter and to contribute to the industrial setting. Hence, migration of talent into these types of industries does not gain much from temporary visits" (HøGNI Kalsø, Vang \& Asheim 2005, p. 19).

The knowledge-base argument concerning specific mobility needs in different industry sectors can be confirmed by applying the varieties of capitalism approach (HALl \& SosKice 2001). Accordingly, Austria provides an example of a coordinated market economy. Economic agents acting in such economic environments rely more heavily on non-market forms of coordinating their endeavours with other actors. Given this relatively high degree of coordination and long-term orientation instead of competition and rather short-term orientation, firms and households in coordinated market economies face several incentives to invest into specific and co-specific assets rather than in general and switchable assets. Typical examples for such specific assets are firm- and industry-specific training schemes and human capital investments (Backes-Gellner, Mure \& Geel 2009). As a result, employees have to remain either in the same firm or industry to reap the respective returns from training or education. Firm relations are less based on direct competition inside an industry, but rather on product differentiation and niche production for often global markets. This, in turn, increases the need for a highly-specialised workforce; firms and workers are bound together in rather long-term relationships in order to maximise the returns of specific assets. As a consequence, labour markets are not as fluent and flexible as in liberal market regimes and the mobility level is generally lower since human capital in the form of switchable assets is rather scarce. The important point is that these factors are preconditions for the production regime of DQP and the comparative advantage of the Austrian manufacturing sector. Taking these factors into account, it becomes clear that the prospects for short-term circulation of a highly-skilled foreign labour force are rather limited. Knowledge spillover agents are traditionally no important part of this system, as stated by Hall \& Soskice (2001, p. 26): "Since many firms in coordinated market economies make extensive use of long-term contracts, they cannot rely as heavily on the movement of scientific or engineering personnel across companies, to effect technology transfer, as liberal market economies do."

In conclusion, there seems to be an ongoing transition inside the Austrian manufacturing sector with crucial consequences for the prospects, usefulness and modes of attracting highly-skilled workers. On the one side, the emerging high-tech sector is dominated by an analytical knowledge base and a need for a general skilled and university educated workforce facilitating recruitment even on European and global labour markets, providing possibilities to utilise foreign talent even on the basis of short-term contracts according to the model of brain circulation or diaspora policies 
(see Appendix B). On the other side, firms producing under the DQP mode rely more on a synthetic knowledge base and long-term contracts with their employees, i.e. on a higher degree of stability of the labour force (FISCHER 2001), thereby favouring internal $\mathrm{BCP}$ such as continuing education on and off the job, recruitment strategies relying on regional and national labour markets, and low rates of labour force fluctuation. However, a one-sided reliance on highly-specialised regional and national educated talent may lead or contribute to negative lock-in effects of industrial clusters and trigger the emergence of old industrial regions. Thus, the attraction of external knowledge spillover agents providing the necessary new knowledge and skills to overcome those negative lock-in effects may be an occasionally important asset even in industries and regions based on DQP (TÖDTLING \& TRIPPL 2005). Inter alia, these arguments may provide rationality for a regionally differentiated BCP based on locally agglomerated systems of production differentiated along the line of DQP versus high-tech. However, some caution is needed because of the large variety of tasks within specific branches, an increasing variety of knowledge sources and inputs for R\&D activities and the lack of clear-cut possibilities for differentiation (AsHeim \& GERTLER 2004).

\section{Austria's "European paradox" and the university sector}

Universities are often and increasingly perceived as key institutions for knowledgedriven regional growth (Етzкоwiтz \& Dzisah 2008). A soaring number of national and regional policy makers ask universities to cooperate with the business sector more intensively. However, the traditional role of teaching and providing the economy with a highly-educated workforce is still a central task regarding university capabilities of fostering upgrading and growth. Indeed, policy makers should according to FLORIDA (1999, p. 10) - contribute to "[the] strengthening [of] the university's ability to attract the smartest people from around the world - the true wellspring of the knowledge economy." Furthermore, the large inflow of foreign talent into the US is not, as it is often claimed, predominantly based on attractive immigration regimes. PERI (2007) asserts that the main factor pulling those talent flows to the US is the presence of America's elite research institutions and superior career opportunities. Hence, attracting talent may well depend on the performance of universities: World-class universities generally outperform mediocre and inward-looking universities with respect to taping "rising and established star scientists" (SChiller \& Revilla Diez 2008). Thus, the thesis of the "European paradox" is of interest. According to this thesis, European universities are world-class and even superior to US universities while the highly valuable output remains locked inside the universities, failing to spill over to the corporate sector. As a result, EU universities should be quite competitive in hiring world-class academic talent. 


\subsection{Competition for faculty}

The current Austrian research and technology report (BMWF, BMVIT \& BMWFJ 2009) evaluates the "European paradox" for the Austrian context. One of the most important indicators for evaluating the scientific excellence of university systems is the number of highly-cited researchers per 1,000 researchers (for a critical discussion of citation-indicators conf. LINDSEY 1989). The results are rather unambiguous: Austrian universities and scientists perform much weaker by citation indicators than those in the US and even in other small open economies like Switzerland, Sweden or Denmark (see Fig. 6). While the density of highly-cited researchers per 1,000 researchers in Sweden is five times higher than that of Austria, the respective number for Switzerland is fourteen (!). Besides a shortfall in cutting-edge research output, Figure 6 demonstrates that even the average number of publications per Austrian researcher is under the EU-15 average. Additional measures for the reputation of the Austrian scientific system are the international university rankings (e.g., Shanghai Jiao Tong Academic Ranking of World Universities). Despite some justified criticism of these indicators, the general picture is clear: Even the two best performing Austrian universities, the University of Vienna and the Vienna University of Technology, show a constant average performance in quantitative terms and a less than average performance in qualitative terms in every important university ranking (JANger 2009; Aghion et al. 2008; Ederer, SChuller \& Willms 2008). Hence, the crucial proposition of the "European paradox", namely a high presence of world-class universities and researchers, clearly does not exist in Austria. Referring to the before-mentioned "Austrian paradox", this result contrasts with the high-income position of the Austrian economy (JANGER \& PECHAR 2008).

The presence of high-performing universities is of utmost importance in the competition for scientific talent. This is partly due to strong agglomeration effects in scientific work: Scientific talents who want to make a scientific career try to become spatially adjacent to the leading scientists in their respective fields of research in order to benefit from their tacit knowledge and external effects of human capital (LuCAS 1988). The geography of "star scientists", a concept introduced by ZUCKER \& DARBY (2007), is shaped by the mobility of star scientists from places with few peers to those places with many in their fields. As a result, the cohorts of star scientists become increasingly concentrated during their life-cycle, leaving regions without existing agglomeration advantages and globally acknowledged prestige for scientific excellence deprived of their best talent (Florida 2007; Maier, KurKa \& Trippl 2007). The importance of the spatial co-presence of star scientists is not only due to the fact that they act as attractors for students from around the world as well as for other leading scholars; they also play a crucial role in establishing efficient university-industry linkages and new company start-ups, providing their residence region with a headstart in leading high-tech industries (Schiller \& Revilla Diez 2008). ZucKer \& DARBY (2007) demonstrated that the spatial co-presence of star scientists in the field of biotechnology leads to a significantly higher number of highly-localised successful spin-offs in the biotechnology sector, often with star scientists as shareholders or co-founders. 


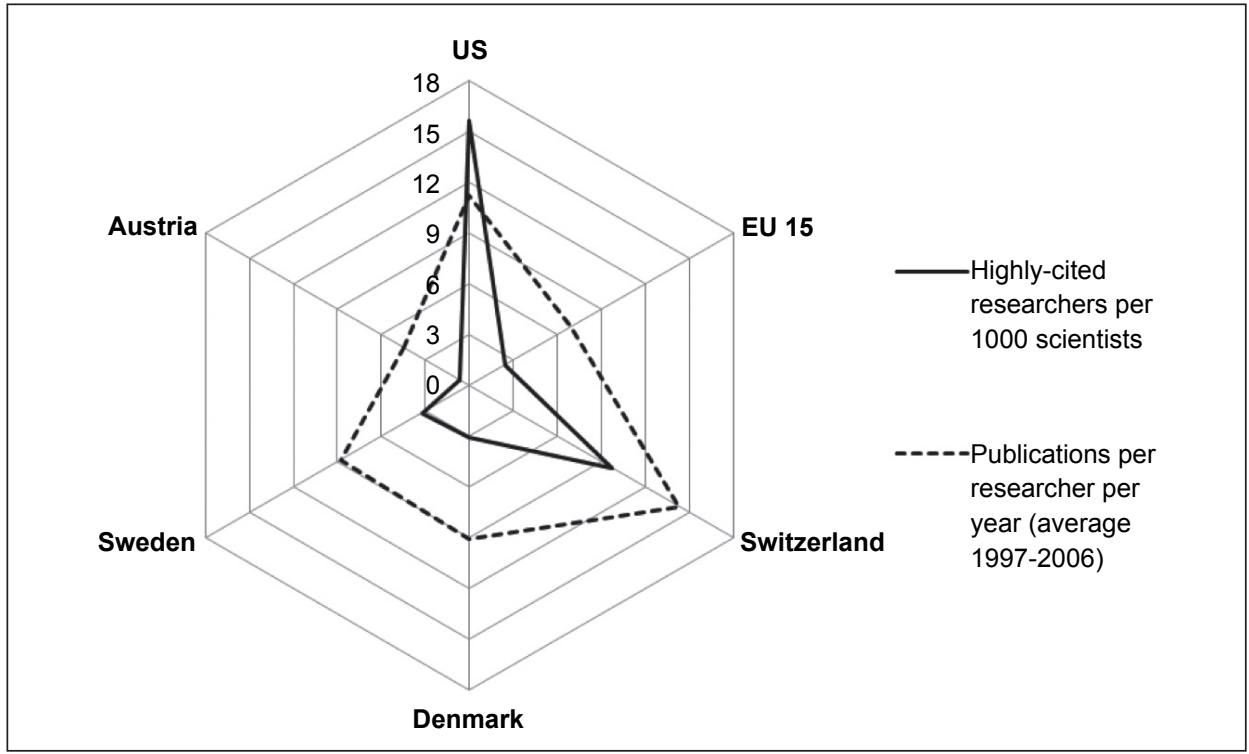

Data: BMWF, BMVIT \& BMWFJ 2009

Fig. 6: Productivity and excellence of scientists in the US, EU and small open European economies. Highly-cited is defined as the top 250 most highly cited researchers for 21 disciplines according to ISIHighlyCited.com

Further impediments for hiring young talented post-doc researchers and assistant professors as well as driving forces for brain drain of Austrian scientists mainly to the US or Canada are the following: First, - a factor which is seen as crucial for the development prospects of universities and innovation activities - is a university organisation which provides young researchers with too little autonomy and unsustainable career prospects, i.e. there is no tenure track which means high risks for the individual researcher to invest into university-specific human capital (MORANO-FOADI 2005; Janger \& Peachar 2008; Backes-Gellner, Mure \& Geel 2009). Second, Austria has the highest share of "general university funding" of all European countries, prohibiting specialisation and the establishing of critical masses to develop comparative advantages in certain research fields (BIFFL 2007). Even more, university funding is far below that of the US or the Nordic countries: While Austria spends $1.5 \%$ of GDP on higher education (public and private), the respective numbers for other countries are as follows: US: $3.3 \%$, Denmark: 2,7\%, Finland: $2.2 \%$, Sweden: $2.3 \%$ (AGHIon et al. 2008). The numbers for spending per student generally reveal an even larger shortfall of Austrian university funding. For instance, Sweden and Denmark on average spend roughly the double sum on the education of each student. Since countries with higher spending show better research performances, this contributes to an unfavourable upshot characterised by significant differences in research performance and hence possibilities to undertake "frontier research" between Austria and other comparable countries (Aghion et al. 2008). In sum, the distance of the Austrian universities to the 
cutting-edge performers is quite big. Thus, Austria fails to attract a significant number of top-notch scientific talents and researchers and suffers from a brain drain of those national talents possessing the resources and possibilities to harness human capital externalities of star scientists abroad (ScheibelHofer 2003; HaAs 2008).

\subsection{Competition for students}

Universities act as potential magnets not only for university researchers but also in the competition for students (ILO 2006; BIFFL 2004). The education of foreign students staying after their graduation in the foreign country is perceived as a best practice model for a long-term oriented highly-skilled immigration policy (ZIMMERMANN 2008). However, the EU as well as Austria still lack an adequate regulatory framework to utilise this so-called "academic-gate approach" as GäCHTER points out (2007, p. 140): "Almost paradoxically European member states in their migration policies have tended to pay little attention to where degrees were obtained. Virtually no effort has been made to retain in-country graduates. From an employment point of view there clearly is the case for adapting migration law to treat them as natives." Two main advantages of the "academic-gate approach" stand out: First, foreign graduates receive nationally-accepted certificates, which reduces the risk of brain waste. This is especially important for Austria because recognition of foreign university certificates is rather arbitrary, and highly-sheltered labour markets for, e.g., teachers prevent foreigners from utilising their human capital adequately to their educational attainment (HAas 2008). Second, nationally-educated talent has already acquired crucial language skills as well as institutional knowledge necessary to harness the benefits of the human capital investment successfully (ILO 2006). Accordingly, policy agents and university management, mainly motivated by the prospect of additional revenues from student fees, set measures in order to attract foreign students, which has in turn triggered a rather intensive competition for globally mobile students (OECD 2009; ILO 2006; BIFFL 2004).

Given the importance of foreign students, it has to be asked how competitive the Austrian universities are in the attracting of foreign students. Generally speaking, they are quite successful. Table 1 shows that Austria has a higher share of foreign students than comparable countries like Sweden or Finland. A recently published OECD (2008) study reported that Austria has even the fourth highest share of foreign students among all OECD countries, after Luxembourg, Switzerland and Australia. However, regarding the share of students from the top-ten source countries as an additional indicator of the attractiveness of university systems for foreign students, a mixed picture arises. The fourth column in Table 1 indicates that Austria has the highest concentration on its ten most important source countries of foreign students; the source countries are mainly neighbouring countries (especially Germany because of institutional arbitrage of German students due to the so-called Numerus Clausus in Germany and generally free university access in Austria). Accordingly, Austria fails to attract mobile students from a wider range of countries. Referring to the economic effects of a foreign student population highly-concentrated on a few source countries, some negative effects are 


\begin{tabular}{|l|c|l|c|}
\hline Country & $\begin{array}{c}\text { Share of foreign } \\
\text { students (2005) }\end{array}$ & Country & $\begin{array}{c}\text { Share of foreign students from } \\
\text { the top ten source countries } \\
(\mathbf{2 0 0 2 / 2 0 0 3 )}\end{array}$ \\
\hline Australia & 17.3 & Denmark & 38.3 \\
\hline UK & 13.9 & Sweden & 44.9 \\
\hline Switzerland & 13.2 & France & 47.9 \\
\hline Austria & $\mathbf{1 1 . 0}$ & Germany & 49.0 \\
\hline France & 10.8 & UK & 55.5 \\
\hline Germany & 10.7 & USA & 57.3 \\
\hline Ireland & 6.9 & Finland & 58.5 \\
\hline Netherlands & 4.7 & Switzerland & 61.6 \\
\hline Denmark & 4.4 & Italy & 61.7 \\
\hline Sweden & 4.4 & Spain & 63.8 \\
\hline Portugal & 3.9 & Netherlands & 70.0 \\
\hline Finland & 3.6 & Ireland & 72.7 \\
\hline USA & 3.4 & Poland & 74.1 \\
\hline Hungary & 2.7 & Australia & 75.4 \\
\hline Italy & 1.9 & Portugal & 82.7 \\
\hline Spain & 1.0 & Hungary & 84.6 \\
\hline Poland & 0.4 & Austria & $\mathbf{9 7 . 1}$ \\
\hline
\end{tabular}

Data: EDERER, Schuller \& Willms 2008

Table 1: Share and concentration on the top ten source countries of foreign students

possible. Recent studies on entrepreneurship revealed a high and statistically significant positive causal relationship between the intensity of new-technology-oriented firm foundations and cultural diversity. The argument is that diversity triggers higher rates of firm entries because the same idea may be valued differently by diverse economic agents, leading to knowledge spillover entrepreneurship. "After all, if all economic agents were perfectly homogenous, a total consensus would reign with respect to any new idea, and there would be no reason to start a new firm" (AUDRETSCH \& Dohse 2009, p. 3). Furthermore, the increasing importance of non-European markets for Austrian exporters points to the need of highly-skilled employees from these new export markets in order to facilitate market entrance and trade issues (Aiginger 2008). Again, the high concentration of mainly European source countries for foreign students can deteriorate the prospects of a successful diversification of Austrian export markets because of a lack of diversity of foreign talent.

The high share of foreign students would lead us to expect a rather high share of foreign highly-skilled people living and working in Austria, e.g., due to retention via personal ties or perceived job opportunities resulting from internships at Austrian 
firms. Yet, as already seen in Figure 1, this is not the case. On the contrary, the high share of foreign students does not lead to an upgrading of the qualification structure of foreign-born people residing in Austria. Hence, Austria is a rather "slippery space" (MARKUSEN 1996) for foreign students since the scientific and business sector are not able to capture and retain a significant share of foreign students. Instead, most of the foreign students leave Austria after their student sojourn. This is exactly the opposite of what happens in the US: "During the closing decades of the $20^{\text {th }}$ century, roughly $80 \%$ of the Chinese and Indians who earned U.S. PhD.s in science, technology, engineering and mathematics fields have stayed in the United States and provided a critical boost to the nation's economy" (WADHwa 2009, p. 46). However, even if a larger proportion of foreign students stayed for a longer period in Austria, some problems would remain. By international comparison, a relatively large share of foreign students study arts or humanities, a quality of human capital which is already rather oversupplied by native students (Bock-Schappelwein, Bremberger \& Huber 2008). Since the industrial structure and economic performance of the Austrian economy heavily depend on a very dynamic manufacturing sector, there is a strong and even increasing demand for graduated natural scientists and engineers. Again, the picture for foreign students in the US is quite the - favourable - opposite: A large share of the foreign students, primarily from Asian countries, study science or engineering, thus compensating for the decreasing number of natives studying management or law (PERI 2007). In short, Austria generally fails to attract a diverse range of students with complementary fields of study for supplying the business sector with human resources in science and technology. Furthermore, those foreign students who choose Austrian universities leave the country after a rather short period of study. Given the lack of internationally competitive $\mathrm{PhD}$ programs and career perspectives, the current policy initiatives towards "excellence clusters" might fail to deliver the desired results, namely to establish Austria as a "sticky place" for global and European scientific talent (FWF 2006; Janger \& Pechar 2008).

\section{Conclusion, discussion and policy implications}

A highly-skilled workforce is of utmost importance for rich countries to prosper under conditions of accelerated globalisation and locational competition. Descriptive statistics reveals a rather weak situation for the Austrian economy: Neither foreign talent nor native talent seems to be available on an adequate quantitative as well as qualitative level. The paper investigates the preconditions and prospects for Austria in the European and global competition for talent (managers, engineers, scientists and students) under the framework of Brain Competition Policy (BCP), defined as the attraction, retention, education, circulation and utilisation of talent. Section two demonstrates that small open economies have a higher need to manage their human capital issues via BCP by identifying four stylised facts: First, a higher degree of openness regarding trade and a stronger dependence on cross-border R\&D activities 
point to the need of foreign highly-skilled workers with the necessary know-how to manage those complex transactions and co-operations in a generally unknown environment. Second, small states have higher rates of brain drain, which leads to the need of diaspora and circulation policies, utilising native talent residing abroad in situ and maintaining the connection with the national innovation system. Third, the drawback of relatively small labour markets may be overcome by regional integration, e.g., by the European Research Area (ERA). Fourth, the high share of SMEs suggests an active $\mathrm{BCP}$ to support the hiring and attraction of the needed skills beyond the borders of the region or nation to back up structural disadvantages of SMEs compared to MNEs on the labour market for highly-skilled workers.

After discussing the importance of BCP for small open economies in general, the article scrutinises the structural preconditions provided by the Austrian corporate and university sector by looking at the "Austrian paradox", i.e. a stable macroeconomic performance despite a lack of high-tech industries, and at the "European paradox" in Austria, which states the presence of world-class universities but the absence of effective university-industry linkages. The Austrian corporate sector is generally characterised by a lack of high-tech industry, at least compared to countries showing a comparable level of wealth. Hence, the absence of visible high-tech clusters and high-tech firms reduces agglomeration forces necessary to substantially pull foreign talent to Austria. However, even the national educational system does not deliver the necessary workforce for a structural change towards high-tech. A lack of tertiaryeducated individuals in general and scientists and engineers in particular is - inter alia - the outcome of an education system still dominated by a formerly very successful matching of a catching-up industrial structure and a quite specialised secondary education system. Hence, the young high-tech sector in Austria has to rely on foreign talent to fill existing knowledge gaps and to profit from knowledge spillover agents providing tacit knowledge not available regionally or nationally. Furthermore, it is demonstrated that the still very competitive traditional manufacturing sector producing under the DQP mode of production and the emerging high-tech sector have quite different needs and prospects to gain from different BCP measures. This may provide rationality for regionally and sectorally differentiated BCPs.

The "European paradox" does not exist in Austria - at least not in the sense of world-class universities. Austrian universities show a rather mediocre performance measured by international standards of performance. A lack of highly-cited researchers or star scientists and a number of other unfavourable factors dampen the prospects to attract foreign star scientist and young ambitious researchers. To the contrary, Austrian universities have a high share of foreign students. This may point to a strong competitiveness in the competition for students. However, most of these students leave Austria after their study sojourns. Furthermore, Austria has a very low diversity regarding the source countries of the foreign students. Recent research on entrepreneurship, demonstrating the importance of diversity for firm start-ups, and the need of Austrian exporters to diversify their export markets, suggests a comparative disadvantage resulting from this low diversity among foreign students. 
In short, Austria as a small open economy has a strong need for BCP and foreign talent but the structural preconditions provided by the university and corporate sector point to a rather unfavourable market situation in the competition for talent. Another relevant aspect refers to the missing policy coordination between a facilitation in legislation regarding residence and work permit for foreign highly-skilled workers and a still high level of xenophobia in society, occasionally nurtured by an increasingly tight and frequently non-humanitarian asylum policy and a traditionally bad management of immigration policy issues resulting in discrimination and brain waste (GÄchter 2004; Mahroum 2005). Due to negative policy spill-overs, this creates an image problem and prohibits the successful attraction of foreign talent (HAAs 2008). Following FlORIDA, low barriers to entry due to a high degree of diversity and cultural openness are crucial preconditions for nations and regions "in the competition for talent or human capital, and in turn, in their ability to generate and attract high-technology industries and increase their incomes" (FLORIDA 2002, p. 745).

According to a recent study on the economic effects of immigration to Austria, the qualification level of the immigrants has risen in the course of time due to policy actions favouring the inflow of foreign highly-skilled workers. However, this rise has not been sufficient to close the qualification gap of the Austrian immigrant society compared to other countries (Bock-SchappelweIN et al. 2009). Taking into account the structure and performance of the Austrian scientific and corporate sector, the lack of openness towards foreigners as well as the phenomenon of self-propelling chainmigration (WALDORF 2009), whereby low-skilled immigrants tend to attract other low-skilled immigrants and vice versa, these results may not be surprising.

Last but not least it might be questioned if "simply" attracting foreign talent is always the optimal strategy. Upgrading and expanding national institutions of higher education towards the needs of knowledge-driven economic development aligned with regional economic structures seems to be of equal importance and may concomitantly foster the prospects in the competition for talent. This option might gain importance in the future inter alia because of a drying out of the market for highly-skilled migrants due to ageing and catching-up processes in traditional source regions (ТiсHY 2008; EDERER, SchUlLer \& WiLlms 2007). In addition, the article demonstrates the importance of networks, regional integration and the presence of a highly-skilled diaspora. This points to new tasks for regional and national policy makers such as network generation, diversity management, boundary spanning and mediation between spatially dispersed but socially connected native and foreign talent in order to facilitate knowledge spillovers and collective learning processes (B ATHELT 2006). Some policy initiatives at the national and regional level like the network initiative "Upper Austrians abroad" or "Austrian Scientists and Scholars in North America" (ASCINA) provide interesting and possibly valuable new instruments for a progressive Austrian BCP. 


\section{References}

Aghion P. et al. (2008), Higher aspirations: An agenda for reforming European universities (= Bruegel Blueprint Series, 5). Brussels.

Agrawal A., Cockburn I., McHale J. (2009), Gone but not forgotten: knowledge flows, labor mobility and enduring social relationships. In: Journal of Economic Geography, 6, pp. 571-591.

Aiginger K. (2004), Wirtschaftswachstum: Grundvoraussetzung für Wohlfahrtszuwachs. Spielräume zur Anhebung des Wachstumspfades. In: Wirtschafts- u. Sozialpolitische Zeitschrift, 3 , pp. 35-58.

Aiginger K. (2008), Herausforderungen für Österreichs Außenwirtschaft im nächsten Jahrzehnt. In: Bundesministerium für Wirtschaft und Arbeit (ed.), Das österreichische Außenwirtschaftsleitbild, pp. 15-32. Wien.

Alesina A. (2003), The size of countries: Does it matter? In: Journal of the European Economic Association, 2-3, pp. 301-316.

Asheim B.T., Gertler M.S . (2004), The geography of innovation. Regional innovation systems. In: Fagerberg J., Mowery D.C., Nelson R.R. (eds.), The Oxford Handbook of Innovation, pp. 291-317. Oxford

Audretsch D.B. (2001), Knowledge in the new economy. In: Wirtschaftspolitische Blätter, 2-3, pp. 140-158.

Audretsch D.B., Dohse (2009), Cultural diversity and entrepreneurship: a regional analysis for Germany. In: Annals of regional science, online published, pp. 1-32.

Backes-Gellner U., Mure J., Geel R. (2009), Lock-in-Effekte durch Humankapitalinvestitionen. In: Wirtschaftswiss. Studium, 1, pp. 37-39.

B AтHelt H. (2006), Geographies of production: growth regimes in spatial perspective 3 - toward a relational view of economic action and policy. In: Progress in Human Geography, 30 , pp. 223-236.

Beine M., Docquier F., Schiff M. (2008), Brain drain and its determinants: a major issue for small states (= IZA Discussion Paper Series, 3398). Bonn.

Bergman E.M., Schubert U. (2005), Spillovers and Innovation, Environment and Space: Policy Uncertainties and Research Opportunities. In: Maier G., Sedlacek S. (eds.), Spillovers and Innovations. Space, Environment and the Economy (= Interdisciplinary Studies in Economics and Management, 4), pp. 157-177. Vienna, New York.

BIFFL G. (2004), Increasing university student mobility: A European policy agenda. In: Austrian Economic Quarterly, 2, pp. 2004.

BIFFL G. (2007), Forschungsstandort Wien: Zur Rolle der Humanressourcen. Wien, WIFO.

Bock-SCHAPPELWEIN J. et al. (2009), Die ökonomischen Wirkungen der Immigration in Österreich 1989-2007. Kurzfassung. Wien.

Bock-Schappelwein J., Bremberger C., Huber P. (2008), Kurzfassung: Hoch qualifizierte Zuwanderung in Österreich. In: BUndesministerium Für WisSENSCHAFT UND ForsCHUNG (BMWF) (ed.), Österreichischer Forschungsdialog Ergebnisdokumentation. Wien.

Boeri T, BrÜCKNer H. (2005), Why are Europeans so tough on migrants? In: Economic Policy, October, pp. 630-703.

Boschma R.A. (2005), Proximity and innovation: A critical assessment. In: Regional Studies, 39 , pp. 61-74.

BundeSMinisterium Für INNERES (ed.) (2008), Leitfaden für den Aufenthalt und die Beschäftigung von ausländischen Forscherinnen und Forschern in Österreich. Wien.

BundESMINISTERIUM FÜr WisSENSCHAFT UND FORSCHUNG (BMWF), BUNDESMINISTERIUM FÜr VERKEHR, INNOVATION UND TECHNOLOGIE (BMVIT), BUNDESMINISTERIUM FÜR WiRTSCHAFt, FAMILIE UND 
JugEND (BMWFJ) (eds.) (2009), Österreichischer Forschungs- und Technologiebericht 2009. Wien.

DAVENPort S. (2004), Panic and panacea: Brain drain and science and technology human capital policy. In: Research Policy, 33, pp. 617-630.

Deutsche Bank Research (ed.) (2009), Dynamische Vielfalt als Chance. Mittelstand international (= Aktuelle Themen, 441). Frankfurt am Main.

DocQuier F., MARFouk A. (2006), International migration by educational attainment 1990-2000. In: OzDEN C., Schiff M. (eds.), International migration, brain drain and remittances, pp. 151-199. New York.

DöRRING T., SCHNELLENBACH J. (2006), What do we know about geographical knowledge spillovers and regional growth? A survey of the literature. In: Regional Studies, 40, pp. 375-395.

Dosi G., Llerena P., Sylos Labini M. (2005), Science and technology-industry links and the "European paradox": some notes on the dynamics of scientific and technological research in Europe (= LEM Working Paper Series, 2). Pisa.

Ederer P., Schuller P., Willms S. (2007), The European human capital index: The challenge of Central and Eastern Europe. The Lisbon Council Policy Brief. Brussels.

Ederer P., Schuller P., Willms S. (2008), University systems ranking: citizens and society in the age of the knowledge. The Lisbon Council Policy Brief. Brussels.

Eтzкоwitz H., Dzisah J. (2008), Unity and diversity in high-tech growth and renewal: learning from Boston and Silicon Valley. In: European Planning Studies, 16, pp. 1009-1024.

European Communities (ed.) (2008), Realising a single labour market for researchers. Report of the ERA expert group. Brussels.

European Union (ed.) (2000), Presidency conclusions. Lisbon European Council 23 and 24 March 2000. Brussels.

Falk M., HaKe M. (2008), Wachstumswirkung der Forschungsleistung. Präsentation im Rahmen des Forschungsdialoges. - http://www.bmwf.gv.at.fileadmin/user_upload/forschung/ forschungsdialog/OEsterrForschungsdialog_alle_Praesentationsfolien_0808bmwf.pdf [7.7.2009].

FisCHER M.M. (2001), Innovation, knowledge creation and systems of innovation. In: Annals of Regional Science, 35, pp. 199-216.

Fischer M. (2008), Diversität und die Wirtschaft. Erfahrungen und Perspektiven von Migrantinnen und Migranten in Deutschland (= HWWI Research Paper, 3-15). Hamburg.

FLORIDA R. (1999), The role of university: leveraging talent, not technology. In: Issues in Science and Technology, 19, pp. 1-10.

FLoRIDA R. (2002), The Economic Geography of Talent. In: Annals of the Association of American Geographers, 92, pp. 743-755.

FLORIDA R. (2007), The flight of the creative class. The new global competition for talent. NY.

Fonds ZUR Förderung der Wissenschaftlichen Forschung (FWF) (ed.) (2006), Exzellenzinitiative Wissenschaft. Wien.

Fromhold-Eisebith M. (2002), Internationale Migration Hochqualifizierter und technologieorientierte Regionalentwicklung. In: IMIS-Beiträge, 19, pp. 21-42.

FustTA M. (2007), Towards the new economic geography in the brain power society. In: Regional Science and Urban economics, 37, pp. 482-490.

Gächter A. (2004), Detecting Discrimination against migrants (= ZSI Discussion Paper, 3). Vienna.

Gächter A. (2006), Brain drain from Bulgaria. The evidence and policy options (= ZSI Discussion Paper, 5). Vienna.

Gächter A. (2007), Migration policies for the highly skilled: The case of foreign graduates. In: TARrósy I., Milford S. (eds.), European higher education in a changing world - a view from the Danube region, pp. 137-144. Pécs. 
Gassler H., Nones B. (2008), Internationalisation of R\&D and embeddedness: the case of Austria. In: Journal of Technology Transfer, 33, pp. 407-421.

Gnan E., Janger J., Scharler J. (2004), Ursachen des langfristigen Wachstums - Plädoyer für eine langfristige Wachstumsstrategie. In: Geldpolitik und Wirtschaft, 1, pp. 25-49.

HaAs M. (2008), Humanressourcen in Österreich. Eine vergleichende Studie im Auftrag des Rates für Forschung und Technologieentwicklung. Vienna.

Hall P.A., Soskice D. (2001), An introduction to varieties of capitalism. In: Hall P.A., Soskice D. (eds.), Varieties of capitalism. The institutional foundations of comparative advantage, pp. 1-68. Oxford.

Høgni Kalsø H., Vang J., Asheim B. (2005), The creative class and regional growth: towards a knowledge based approach (= CIRCLE Electronic Working Paper Series, 15). Lund.

International Labour Organisation (ILO) (ed.) (2006), Competing for global talent. Geneva.

JANGER J. (2009), Systemevaluierung der österreichischen Forschungsförderung und -finanzierung. Report 1: Rahmenbedingungen. Vienna.

Janger J., Pechar H. (2008), Kurzfassung: „Bieten Österreichs Universitäten bereits optimale organisatorische Rahmenbedingungen für die Entstehung und Nachhaltigkeit wissenschaftlicher Qualität? In: BUNDESMINISTERIUM FÜR WisSENSCHAFT UND FORSCHUNG (BMWF) (ed.), Österreichischer Forschungsdialog Ergebnisdokumentation. Wien.

J ANGER J., W AGNER K. (2004), Sectoral Specialisation in Austria and in the EU-15. In: Monetary Policy \& the Economy, 2, pp. 37-54.

Kоцв H. (2005), The German "green card”. Focus Migration. Policy brief. Hamburg.

Krugman P. (1991), Geography and trade. Massachusetts.

Krugman P., Obstfeld M. (2009), International economics. Boston et al.

LAND OBERÖSTERreich (ed.) (2005), Innovatives Oberösterreich 2010. Das Strategische Programm erstellt im Auftrag des Landes Oberösterreich. Linz.

Leo H. et al. (2006), WIFO-Weißbuch: Mehr Beschäftigung durch Wachstum auf Basis von Innovation und Qualifikation. Teilstudie 8: Forschung und Innovation als Motor des Wachstums. Wien

LiNDSEY D. (1989), Using citation counts as a measure of quality in science. Measuring what's measureable rather than what's valid. In: Scienomoetrics, 3-4, pp. 189-203.

Lodigiani E. (2008), Diaspora externalities and technology diffusion (= UCL Discussion Paper, 8). Louvain-la-Neuve.

LuCAS R.E. (1988), On the mechanics of economic development. In: Journal of Monetary Economics, 22, pp. 3-42.

Mahroum S. (1999), Competing for the highly skilled: Europe in perspective. In: Science and Public Policy, 1, pp. 17-25.

Mahroum S. (2005), The international policies of brain gain: a review. In: Technology Analysis \& Strategic Management, 2, pp. 219-230.

Maier G., Kurka B., Trippl M. (2007), Knowledge spillover agents and regional development: spatial distribution and mobility of star scientists (= DYNREG Working Paper Series, 17). Vienna.

Manpower (ed.) (2008), The borderless workforce. A Manpower White Paper. Milwaukee.

MARIN D. (2008), The new corporation in Europe (= Bruegel Policy Brief, 7). Brussels.

MARIN D. (2009), The battle for talent: globalisation and the rise of executive pay (= Bruegel Working Paper, 1). Brussels.

MarkuSEn A. (1996), Sticky places in slippery space: a typology of industrial districts. In: Economic Geography, 72, pp. 283-313.

Maskell P. (1999), Social Capital and Regional Development (= North, 5). Copenhagen. 
Maskell P., Malmberg A. (1999), Localised learning and industrial competitiveness. In: Cambridge Journal of Economics, 23, pp. 167-185.

Mayer S., BlaAs W. (2002), Technology Transfer: An opportunity for small open economies. In: Journal of Technology Transfer, 3, pp. 275-289.

Morano-FoAdi S. (2005), Scientific mobility, career progression, and excellence in the European Research Area. In: International Migration, 5, pp. 134-162.

Nerdrujm L., Sarpebakken B. (2006), Mobility of foreign researchers in Norway. In: Science and Public Policy, 3, pp. 217-229.

Organisation for Economic Co-operation and Development (OECD) (ed.) (2008a), Education at a glance 2008. Paris.

Organisation for Economic Co-operation and Development (OECD) (ed.) (2008b), A profile of the immigrant populations in the $21^{\text {st }}$ century. Paris.

Organisation for Economic Co-operation and Development (OECD) (ed.) (2008c), Open Innovation in a global perspective - What do existing data tell us? (= STI Working Paper, 4). Paris

Organisation for Economic Co-operation and Development (OECD) (ed.) (2008d), Science, Technology and Industry Outlook 2008. Paris.

Organisation for Economic Co-operation And Development (OECD) (ed.) (2009), The global competition for talent. Policy Brief. Paris.

Österreichische BundesRegierung (ed.) (2008), Regierungsprogramm 2008-2013. Gemeinsam für Österreich. Wien.

Peneder M. (1999), The Austrian paradox: "old” structures but high performance? In: Austrian Economic Quarterly, 4, pp. 239-247.

Peneder M. (2008), Kurzfassung: Was bleibt vom Österreich Paradoxon? Wachstum und Strukturwandel in der Wissensökonomie. In: BundeSMINISTERIUM FÜR WISSENSCHAFT UND FORSCHUNG (BMWF), Österreichischer Forschung sdialog Ergebnisdokumentation. Wien.

Peri G. (2007), America's stake. In: The Milken Institute Review, 3, pp. 40-49.

Pethe H. (2007), Un-restricted agents? International migration of the highly skilled revisited. In: Social Geography Discussions, 3, pp. 211-236.

Reiner C. (2008a), Nokia, Novartis \& Co: Die Rolle von Standortpolitik und Arbeit im Standortwettbewerb. In: Wirtschafts- u. Sozialpolitische Zeitschrift, 4, pp. 141-172.

REINER C. (2008b), Brain drain und brain gain auf Österreichisch. In: Die Presse, 25/9, p. 37.

Reinstaller A., Unterlass F. (2008), What is the right strategy for more innovation in Europe? Drivers and challenges for innovation performance at the sectoral level. Synthesis report.

Romer P.M. (1990), Endogenous Technological change. In: Journal of Political Economy, 98, pp. 71-102.

SAUter N. (2009), Talking Trade: Language barriers in intra-Canadian commerce (= FIW Working Paper, 23).

SaXenian A.L. (2006), The new argonauts. Regional advantage in a global economy. Boston, Harvard.

Scheibelhofer E. (2003), Brain Gain, Brain Drain oder Brain Waste? Zum Problem der Abwanderung österreichischer WissenschaftlerInnen. In: Wirtschaftspolitische Blätter, 3 , pp. 409-419.

Schibany A. (2008), Wider den Appell. Zum Lissabon-Prozess und andere Anmerkungen. In: Wirtschaft u. Gesellschaft, 4, pp. 563-589.

Schiller D., Revilla Diez J. (2008), Mobile star scientists as regional knowledge spillover agents (= IAREG Working Paper, 2/7). Hannover.

SiEBER S. (2008), Österreichs Attraktivität für ausländische Direktinvestitionen sowie als Standort für Headquarters-Funktionen (= FIW Studien, 21). Vienna. 
Siebert H. (1995), Internationale Migration aus wirtschaftswissenschaftlicher Perspektive. In: Geogr. Rundschau, 7-8, pp. 405-409.

SIEBERT H. (2006), Locational competition: a neglected paradigm in the international division of labour. In: The world economy, 2, pp. 137-159.

Sterlacchini A. (2008), R\&D, higher education and regional growth: uneven linkages among European regions. In: Research Policy, 37, pp. 1096-1107.

StraubHaAR T. (2000), International mobility of the highly skilled: brain gain, brain drain or brain exchange (= HWWA Discussion Paper, 88). Hamburg.

Straubhaar T. (2001), War for brains. In: Intereconomics, September/October, pp. 221-222.

STREEK W. (1991), On the institutional preconditions of diversified quality production. In: Matzner E., Streek W. (eds.), Beyond Keynesianism. The socio-economics of full employment, pp. 21-61. Aldershot.

Tichy G. (2007), 3\% F\&E-Quote genügen nicht. In: Wirtschaftspolitische Blätter, 2, pp. 353-373.

Tichy G. (2008), Woher sollen die Immigranten kommen? Zur Bevölkerungsprognose der Statistik Austria. In: Wirtschaft u. Gesellschaft, 4, pp. 1-18.

Tiroler Zukunftsstiftung (ed.) (2007), Forschung, Technologie und Innovation in Tirol. Eine Standortbestimmung. Studie im Auftrag der Tiroler Zukunftsstiftung. Innsbruck.

TöDtLing F., Trippl M. (2005), One size fits all? Towards a differentiated innovation policy approach. In: Research Policy, 34, pp. 1203-1219.

Tridat A. (2008), The brain drain between knowledge based economies: the European human capital outflow to the US (= CEPII Working Paper Series, 08). Paris.

Trippl M. (2006), Cross-border regional innovation systems (= SRE-Discussion, 5). Vienna.

Trippl M., Tödtling F. (2007), Developing biotechnology clusters in non-high technology regions - the case of Austria. In: Industry and Innovation, 1, pp. 47-67.

WAdHwA V. (2009), Tapping talent in a global economy. A reverse brain drain. In: Issues in Science and Technology, 25, pp. 45-52.

WALDORF B.S. (2009), Is human capital accumulation a self-propelling process? Comparing educational attainment levels of movers and stayers. In: Annals of Regional Science. Published Online, pp. 323-344.

WeIZsÄCKER J. (2008a), Strait is the gate - Europe's immigration priorities (= Bruegel Policy Brief, 5). Brussels.

Weizsäcker J. (2008b), Welcome to Europe (= Bruegel Policy Brief, 3). Brussels.

Zimmermann K.F. (2008), Mobilitätspolitik in Europa. In: Wirtschaftspolitische Blätter, 2, pp. 199-208.

ZuCKER L.G., DARBY M.R. (2007), Star scientists, innovation and regional and national immigration (= NBER Working Paper Series, 13547). New York. 
Appendix A: Main steps in the formation of Austria's BCP

\begin{tabular}{|c|c|}
\hline Year & Event \\
\hline 1938 & Exodus and extermination of Jewish and critical scientists . \\
\hline $\begin{array}{l}\text { after } \\
1945\end{array}$ & $\begin{array}{l}\text { The Austrian scientific system becomes mediocre, inward-looking and endogamy } \\
\text { dominates. }\end{array}$ \\
\hline $\begin{array}{l}1961- \\
1974\end{array}$ & First wave of intended low-skilled immigration ("Gastarbeiter"). \\
\hline 1975 & $\begin{array}{l}\text { A university reform provided a more open university and more possibilities to par- } \\
\text { ticipate for non-professors. }\end{array}$ \\
\hline 1985 & $\begin{array}{l}\text { Establishment of the Erwin SCHRÖDINGER program as a post-doc outgoing program } \\
\text { to increase the mobility of young Austrian elite scientists }\end{array}$ \\
\hline 1990 & $\begin{array}{l}\text { Start of the setup of Universities of Applied Science ("Fachhochschulen") as a new } \\
\text { type of an institution of tertiary education with strong linkages to regional govern- } \\
\text { ments and social partners, thereby fostering the possibilities for regional BCP as well } \\
\text { as the increase of the share of tertiary educated people in general. }\end{array}$ \\
\hline 1992 & $\begin{array}{l}\text { Establishment of the Lise Meitner Program as an incoming program for established } \\
\text { scientists. The foreign researchers should enhance Austria's scientific capabilities } \\
\text { due to cooperation. }\end{array}$ \\
\hline 1995 & $\begin{array}{l}\text { EU accession of Austria: Austria participates from now on in the EU framework } \\
\text { programs; especially important are the "People - Marie Curie actions", funding and } \\
\text { fostering incoming and outgoing mobility of researchers and the respective programme } \\
\text { for student mobility called ERASMUS. The EU budget for Marie Curie under the } \\
7^{\text {th }} \text { framework programme } 2007 \text { to } 2013 \text { amounts to } 4.750 \text { Mio. Euro. }\end{array}$ \\
\hline 1999 & $\begin{array}{l}\text { Foundation of the elite biotechnology research institution IMBA (Institute of Mo- } \\
\text { lecular Biotechnology - ViennaBioCenter) in Vienna }\end{array}$ \\
\hline 2000 & $\begin{array}{l}\text { The Lisbon summit claims to encourage the set up of the European Research Area } \\
\text { "to ensure that Europe offers attractive prospects to its best brains"; "take steps to } \\
\text { remove obstacles to the mobility of researchers in Europe by } 2002 \text { and to attract and } \\
\text { retain high-quality research talent in Europe." } \\
\text { As a response, the Austrian government launched the so called "Forschungsoffensive" } \\
\text { and founded the "Austrian Council for Research and Technology Development". Is- } \\
\text { sues of brain drain and labour market shortages of the highly skilled come to the fore. }\end{array}$ \\
\hline 2001 & $\begin{array}{l}\text { Establishing of the Office of Science \& Technology (OST) and the OST Scientist } \\
\text { Network, an interdisciplinary network of } 1200 \text { Austrian scientists and scholars in } \\
\text { the US and Canada. The aim of this network is to enable a strategic foundation for } \\
\text { understanding the needs of Austrian scientists and scholars in North America. It } \\
\text { also provides a basis for exchanges between the scientific community in Austria and } \\
\text { Austrian scientists in North America. }\end{array}$ \\
\hline
\end{tabular}




\begin{tabular}{|c|c|}
\hline Year & Event \\
\hline 2002 & $\begin{array}{l}\text { Universities become autonomous. } \\
\text { A network of Austrian scientists and scholars in North America (ASCINA) is set up. } \\
\text { ASCINA is an independent, non-official network, based on the voluntary participa- } \\
\text { tion of Austrian scientists currently working in North America. } \\
\text { The summit of Barcelona set the goal to achieve a } 3 \% \text { R\&D quota for the member } \\
\text { states until 2010. The European commission stated that } 500,000 \text { to } 700,000 \text { (!) ad- } \\
\text { ditional researchers are necessary. Austrian policy agents suggest a national gap of } \\
\text { researchers of about } 900 \text {. }\end{array}$ \\
\hline 2003 & $\begin{array}{l}\text { The politically manageable immigration from non-EU countries is limited to highly- } \\
\text { skilled workers under quotas. } \\
\text { The initiative "brain power" is launched. This initiative is destined to facilitate the } \\
\text { return of Austrian scientists abroad, to connect the scientific diaspora with the national } \\
\text { scientific and innovation system and to promote Austria as an attractive location for } \\
\text { foreign researchers. }\end{array}$ \\
\hline 2004 & $\begin{array}{l}\text { The accession of the eight former Communist states in Central Europe was accom- } \\
\text { panied by policy measures to ensure that the Austrian labour market is not distorted } \\
\text { by the immigration of a large number of foreigners from these countries. The entry of } \\
\text { workers from these countries is only possible with specific qualifications (so called } \\
\text { "Fachkräfte"), the contingent and the respective array of occupations is negotiated } \\
\text { every year. } \\
\text { Austria participates in the EU programme of "European Researchers Mobility Portal" } \\
\text { and the "European Network of Mobility Centres". }\end{array}$ \\
\hline 2006 & $\begin{array}{l}\text { Launching of an "excellence strategy". The aim is to promote Austria as an international } \\
\text { attractive location for R\&D and to position the scientific system in the international } \\
\text { competition. The main elements of the project are the founding of an "Institute of } \\
\text { Science and Technology-Austria" (ISTA), the program for centres of competence } \\
\text { (COMET) to facilitate joined research of business and science. The building of "ex- } \\
\text { cellence clusters" in science should promote the building of focal points of scientific } \\
\text { research. The new performance-based funding of universities is thought to trigger } \\
\text { more excellence research at universities. }\end{array}$ \\
\hline 2007 & $\begin{array}{l}\text { The minister for science agreed on a cooperation program with the Czech Republic, } \\
\text { Bulgaria, Slovenia, Hungary, Slovakia, Poland and Switzerland to build and com- } \\
\text { monly use research infrastructure because otherwise there would be no chance for } \\
\text { small countries to compete with states like Germany or France in the attractiveness } \\
\text { of the research infrastructure. }\end{array}$ \\
\hline 2008 & $\begin{array}{l}\text { An amendment allows spouses as well as children of third-country researchers free } \\
\text { entrance to the Austrian labour market. } \\
\text { The Austrian government, together with a number of other EU countries, inhibits the } \\
\text { free movement of EU-blue-card holders between the member states in order to retain } \\
\text { control over national labour-market-related immigration. }\end{array}$ \\
\hline 2009 & $\begin{array}{l}\text { The Austrian government discusses the introduction of a "red-white-red-card", which } \\
\text { should facilitate the entrance of non-EU skilled workers according to defined national } \\
\text { labour market needs. }\end{array}$ \\
\hline
\end{tabular}




\begin{tabular}{|c|c|c|c|c|c|c|c|c|}
\hline 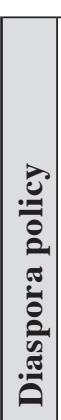 & 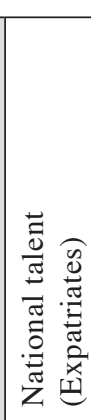 & 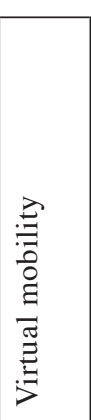 & 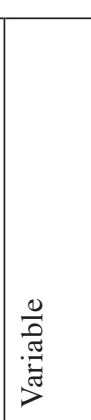 & 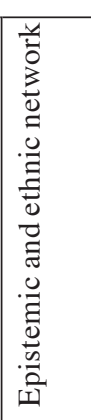 & 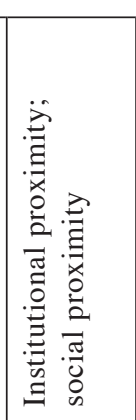 & 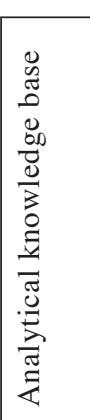 & 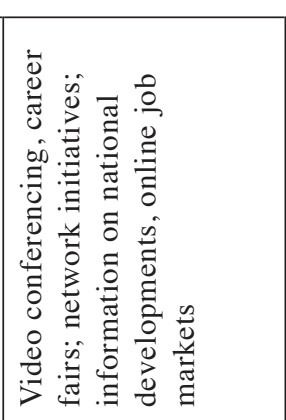 & 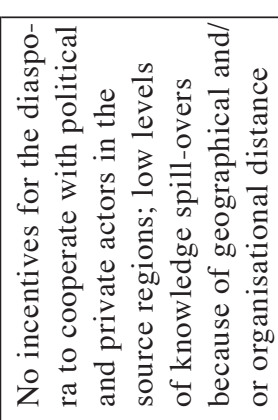 \\
\hline 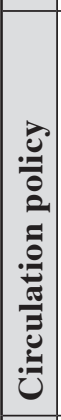 & 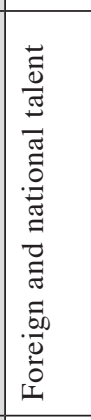 & 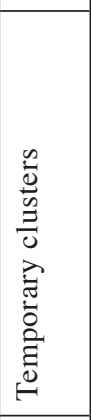 & 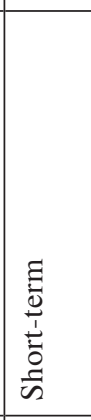 & 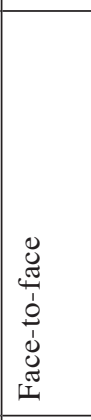 & 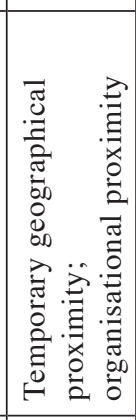 & 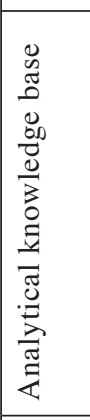 & 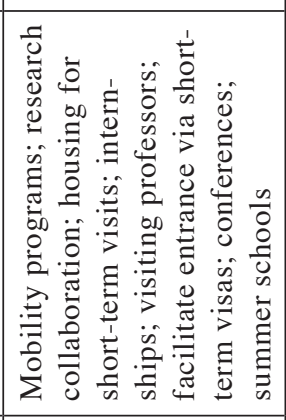 & 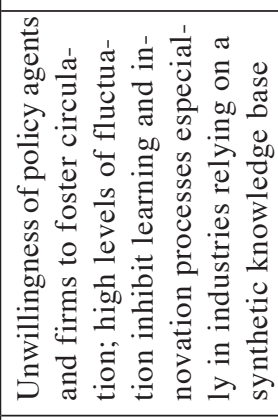 \\
\hline 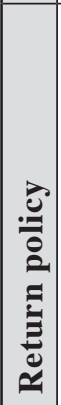 & 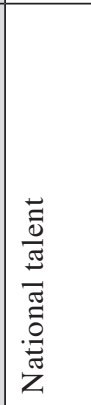 & 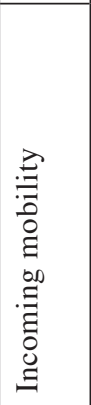 & 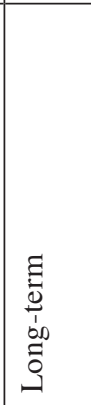 & 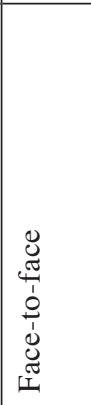 & 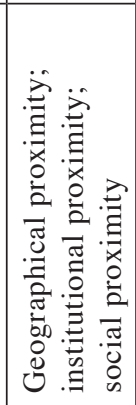 & 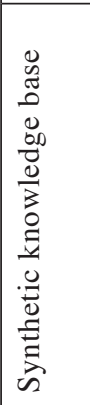 & 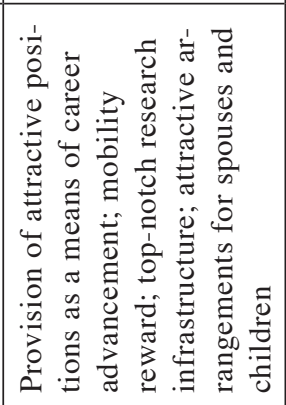 & 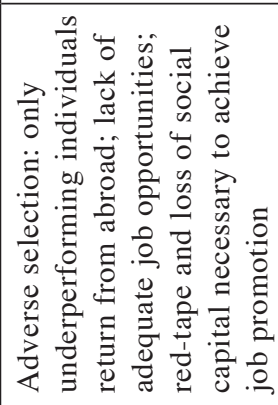 \\
\hline 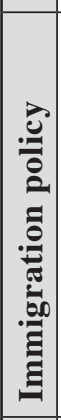 & 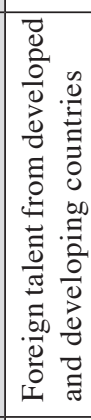 & 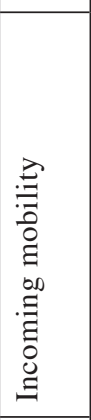 & 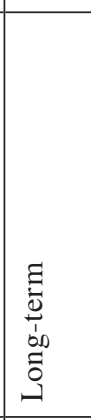 & 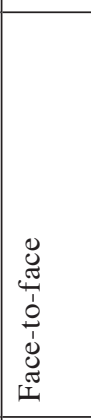 & 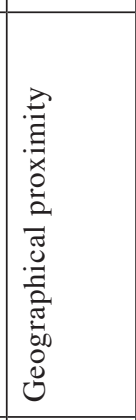 & 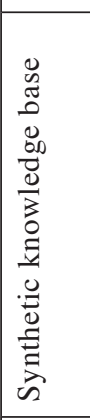 & 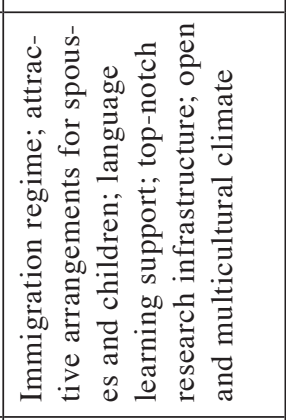 & 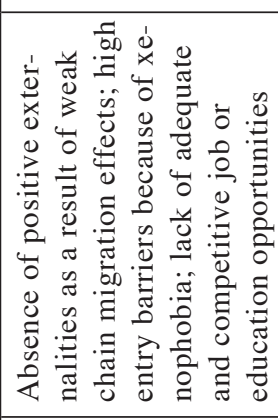 \\
\hline 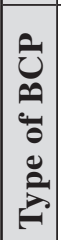 & 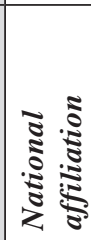 & 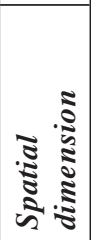 & 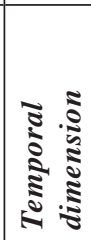 & 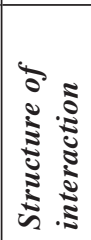 & 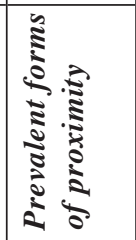 & 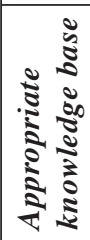 & 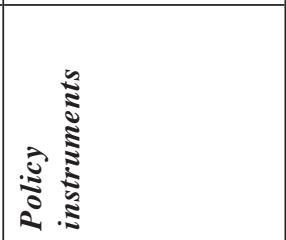 & ڤ్ \\
\hline
\end{tabular}

